\title{
A transformação dos sistemas partidários da Europa Ocidental
}

Nascido em Heilbronn, na Alemanha, Otto Kirchheimer (1905-1955) se tornou um dos maiores constitucionalistas alemães. Estudou direito e sociologia, doutorando-se pela Universidade de Bonn, tendo como seu orientador de tese Carl Schmitt, que, segundo consta, considerava-o seu melhor aluno. Kirchheimer converteu-se ao socialismo ainda jovem e acabou se filiando ao Partido Socialista Alemão. Em razão dessa militância de esquerda e de sua ascendência judaica, migrou para Paris, em 1933, acompanhando seus colegas do Frankfurter Institute fur Sozialforschung, a geração inicial da famosa "escola de Frankfurt", da qual fazia parte. Em 1937, migrou novamente com seus colegas, agora para os Estados Unidos da América, onde foi incorporado à vida universitária e até chegou a ser consultor do Escritório de Estudos Estratégicos, do Departamento de Estado. Lá, pode desenvolver com mais tranquilidade os estudos acerca do principal tema que lhe interessava e que o havia levado a focar seus esforços intelectuais no constitucionalismo. A questão que mais lhe preocupava, por motivos pessoais, inclusive, era a vulnerabilidade da democracia. Como constitucionalista, obviamente, dirigia seu foco investigativo ao problema da concentração de poder. Encarregou-se também de analisar questões relativas à redemocratização da Europa e, principalmente, da Alemanha, depois da Segunda Guerra. Ao mergulhar nesse tipo de problemática, percebeu a centralidade dos partidos políticos para o funcionamento da democracia representativa e, ao mesmo tempo, vislumbrou o processo de transformação pelo qual os partidos europeus estavam passando, o que o levou à caracteri- 
zação do tipo catch-all party. Já em 1954 ele havia chegado a esse conceito, ao analisar o sistema político alemão e constar que os eleitores preferiam votar em partidos catch-all, mesmo que fossem partidos conservadores, e que, por isso, a única condição do PSD continuar competitivo seria se transformar também no tipo catch-all. Kirchheimer via esse processo como algo negativo e que poderia ameaçar a democracia, em decorrência da pouco diferenciação dos partidos e do consequente desencanto dos cidadãos com o governo representativo. Esses estudos o levou a participar do grupo de cientistas políticos e sociólogos comportamentalistas que se dedicavam às análises comparadas do desenvolvimento político. Inclusive, este texto que ora se publica foi o capítulo de um livro que trazia resultados de pesquisas com esse propósito, como parte de uma série de publicações intitulada Studies in Political Development. Na Ciência Política, este texto é um dos mais citados até hoje, e o tipo catch-all também ainda é amplamente utilizado nos estudos partidários em todo o mundo. Embora a maior parte de seus escritos seja na língua alemã e, portanto, inacessível ao grande público, este pequeno trabalho em inglês, mais acessível, portanto, fez de Kirchheimer um dos autores mais conhecidos da área e deste texto uma leitura indispensável aos estudiosos dos partidos e da política em geral.

O texto aqui apresentado foi publicado originalmente em inglês, em 1966, com o título "The transformation of the Western European party systems", $p$. 177-200, como um capítulo do livro Political parties and political development, organizado por Joseph LaPalombara e Myron Weiner, pela Princeton University Press, em Princeton, New Jersey. Há alguns anos, esse mesmo texto foi incluído numa coletânea, organizada por Peter Mair, que reuniu diversos trabalhos altamente relevantes para a área de estudos partidários, intitulada The West European party system, publicada em 1990 pela Oxford University Press, Oxford. Porém, nessa reedição, o texto de Kirchheimer aparece incompleto, pois se suprimiu a primeira seção do capítulo original, de 1966. Em português, esta é a primeira vez que se publica esse texto clássico, e na íntegra ${ }^{1}$.

\section{O conceito de "carga" e as falhas partidárias}

Fiquei tão intrigado com o conceito de "carga", formulado por LaPalombara-Weiner, ${ }^{2}$ que resolvi usá-lo como ponto de partida para a inquirição

\footnotetext{
Texto introdutório, tradução e notas explicativas de Paulo Peres. As notas do tradutor são identificadas pela sigla N.T.; as notas do autor, pela sigla N.K. ("nota de Kirchheimer").

N.T.: Kirchheimer se refere ao primeiro capítulo do livro em que seu artigo foi publicado originalmente,
} 
acerca dos sucessos e falhas dos maiores partidos europeus enquanto correias de transmissão entre a população em geral e a estrutura governamental.

O caso britânico tem uma beleza primitiva: a unidade nacional, erguida no século XVI com a consolidação do establishment, seguida pelos arranjos constitucionais e sociais do século XVII, permitiu um relacionamento osmótico entre a aristocracia e a burguesia. Esses arranjos aconteceram cedo o bastante para evitar os horrores e os concomitantes assaltos políticos do industrialismo do começo do século XIX. Já a suave e gradual integração das classes trabalhadoras se completou tarde o bastante para que a enervação da clivagem entre a promessa política e a efetividade social da democracia (a "crise de distribuição", de LaPalombara e Weiner) durasse apenas um par de décadas dos governos MacDonald e Baldwin. ${ }^{3}$ Assim, se omitido o interlúdio de 1910-1914, a Grã Bretanha apresenta-se como um caso no qual os problemas poderiam ser tratados como cargas únicas. Desse modo, o fator

\footnotetext{
"The origin and development of political parties", no qual seus autores, Joseph LaPalombara e Myron Weiner utilizam os conceitos de "carga" (load) e de crise (crisis) para analisar os diferentes percursos históricos que cada sistema partidário percorreu para conseguir se desenvolver, cada qual à sua maneira, vis-à-vis certas "cargas" históricas situacionais, estruturais, relacionadas às habilidades das lideranças, etc. Este trecho do texto daqueles autores é bem ilustrativo quanto ao conceito: "frequentemente, os partidos surgem a partir de situações de crise. Em algumas circunstâncias, eles são criaturas de uma crise política sistemática, enquanto em outras circunstâncias sua própria emergência cria uma crise no sistema. Quase sempre, uma crise ocorre em decorrência do fato de que as elites políticas estabelecidas não querem ou não são hábeis para lidar com isso de modo a inibir o estabelecimento de organizações políticas de oposição. Essas crises históricas então colocam uma "carga" sobre o sistema político tradicional, que tanto pode resultar na organização dos partidos políticos como, na verdade, ser causada pela emergência dos partidos. (...) O ponto que queremos defender aqui é que as crises históricas não apenas frequentemente suprem o contexto no qual os partidos políticos emergem pela primeira vez, como também tendem a ser um fator crítico na determinação de qual padrão a evolução dos partidos tomará posteriormente" (p. 13-14).

3 N.T.: Stanley Baldwin (1867-1947) e James Ramsay MacDonald (1866-1937) foram políticos importantes da primeira metade do século XX no do Reino Unido. Os dois chegaram ao cargo de primeiro-ministro, sucessivas vezes nos anos 1920 e 1930. Baldwin era de uma família de industriais bastante ricos e ligados à política, filiado ao Partido Conservador. MacDonald vinha de uma família pobre do interior da Inglaterra, mas mudou-se para Londres, onde teve boa educação e acabou se casando com a filha de John Gladston, membro de uma família também muito rica. Foi um dos fundadores do Partido Trabalhista e viria a ser a primeiro primeiro-ministro trabalhista britânico. Os dois governaram durante um período bastante conturbado, com instabilidade nas relações internacionais depois da Primeira-Guerra e com os lances iniciais do que viria a culminar na Segunda Guerra. Do ponto de vista econômico, enfrentaram a grande depressão depois do colapso de 1929. Nesse período também o Partido Trabalhista finalmente ultrapassaria o Partido Liberal em termos eleitorais, tornando-se o segundo partido mais importante do sistema bipartidário britânico. Outra peculiaridade dessa época é que, durante os mandatos de Baldwin e MacDonald, se formaram três coalizões de governo, algo raro na política inglesa, sendo uma delas entre os trabalhistas e conservadores, o que causou a expulsão de MacDonald das fileiras do Partido Trabalhista.
} 
temporal se funde e coincide com o fator carga. O impacto do constitucionalismo se manifesta lentamente no século XVIII; então, durante o século XIX, segue-se a aceleração da classe média e o início da integração da classe trabalhadora, assim como a tempestuosa combinação das consequências da plena democratização política com as demandas por uma sociedade distributiva, após a Primeira Guerra Mundial.

Aonde chegaremos se aplicarmos o conceito de carga única ao caso francês? Se havia um problema de identidade nacional na França, ele foi quase superado em 1793, uma vez que a revolução apenas intensificou os resultados, em princípio, alcançados em 1590. O sufrágio universal, ou seja, a democracia política como a base constitucional do Estado francês, manteve-se quase continuamente na agenda desde 1848, e foi plenamente obtido no começo dos anos 1870. Quaisquer que tenham sido as rusgas nas relações entre Executivo e Legislativo, jamais foi contestada a base popular do regime francês, exceto pelo efêmero período pétainiste. ${ }^{4}$ Mas, por que a integração política, o negócio de transformar o aparelho de Estado da sociedade burguesa num empreendimento cooperativo de todas as classes, teve sucesso tão curto? Por que será que essa meta foi alcançada somente agora, pelo menos até certo ponto, como um simples subproduto do aumento do bem-estar material e da consequente redução do antagonismo social na espécie francesa de sociedade industrial? Como é que os partidos políticos contribuíram tão pouco para esse resultado final?

\footnotetext{
4 N.T: O autor se refere ao governo de Henri Phillipe Pétain (1864-1951). Ele foi uma figura ímpar na recente história política francesa. Militar de grande destaque na Primeira Guerra, quando atuou como comandante-em-chefe das forças militares francesas, chegando a ser nomeado Marechal, em 1918, Pétain enveredou-se pela carreira política e chegou a ser ministro da guerra, em 1934, e embaixador na Espanha, em 1939, deixando o cargo para se tornar vice-primeiro-ministro do país. A partir daí, sua biografia seria irremediavelmente manchada pelas cores do nazismo. A França declarou guerra à Alemanha no começo de setembro de 1939, logo apos a invasão nazista à Polônia. No início de Maio de 1940, os alemães iniciam sua ofensiva mais agressiva e invadem a França, chegando a Paris em Junho do mesmo ano. Pétain, então vice-primeiro-ministro, e Máxime Weygand, general chefe do estado-maior, defenderam veementemente a posição de que a França não deveria investir numa guerra que seria perdida, e que a melhor alternativa era assinar um armistício com a Alemanha. Na prática, isso significaria a rendição francesa e sua futura colaboração com o regime nazista. Recusando-se a se render, Paul Reynaud, então o primeiro-ministro, renunciou ao cargo, dando lugar ao vice Pétain. Em 22 de Junho de 1940, foi assinado o acordo com os alemães, o qual previa a divisão da França em territórios ocupados e não-ocupados, a redução do efetivo das forças armadas, o pagamento dos custos da ocupação e a entrega de todos os judeus franceses à Alemanha. Pétain governaria o território não-ocupado, totalmente colaboracionista, cuja sedo do governo seria Vichy. No governo, assinou decretos que, na prática, suprimiam os dispositivos da Constituição da Terceira República, de 1875, e lhe atribuíam amplos poderes.
} 
Há razões pelas quais a sociedade francesa, a despeito ou por causa da precoce introdução do sufrágio universal, poderia forçar sua classe trabalhadora a aceitar a posição de tutelada. Eles eram minoritários numa sociedade não particularmente favorável à ruptura do equilíbrio social existente em decorrência de uma acentuada industrialização. Mesmo sem tal industrialização, havia pouca chance de criação de um sistema partidário unificado. Ao invés disso, existia uma dicotomia entre os partidos de representação individual (com sua dupla base, na paróquia local e nas operações das facções parlamentares) e o incipiente partido de massas da classe trabalhadora, o Partido Socialista da primeira década do século. Em sua maioria, os partidos burgueses se mantiveram estritamente como organizações eleitorais, com conexões soltas para facções parlamentares ainda mais soltas, restando-lhes pouco raio de ação para além da cena legislativa (o equivalente à noção de partidos criados internamente, de Duverger-LaPalombara-Weiner). ${ }^{5}$

Graças à cortesia de Alain (1925), esses partidos foram equipados com uma teoria ultrademocrática da eterna vigilância, a ser exercida pelo proverbial homem comum sobre seus intermediários no partido e no parlamento. Mas a realidade era bastante diferente. Por trás da fachada da vigilância democrática, a fragmentação política excluiu-os do avanço que os tiraria do estágio das aglutinações parlamentares ad hoc e os elevaria à condição de correias de transmissão entre a população e o governo permanentemente organizadas. As organizações e convenções partidárias eram desmesuradas confabulações dos raisonneurs do Café de Commerce, sem qualquer mandato efetivo. ${ }^{6}$ Assim, os partidos burgueses e o governo parlamentar que eles apoiavam, a cada turno de eventos, viam-se renegados a meras bolhas sopradas pelo pays légal a serem confrontadas com o pays réel, descoberto a partir da confluência de milhares de vozes discordantes. Além disso, nem os raisonneurs ou os mais ou menos benevolentes intermediários do Comité Mascuraud, cuidando da performance parlamentar dos clãs políticos rivais

5 N.K.: A dicotomia "criação interna-externa" tem que ser vista à luz da presença ou ausência de enquadramento de apoio de organizações paralelas, como as religiosas ou de motivação classista. O comitê local do partido burguês, criado internamente, e seus financiadores nunca podem servir como escora à prova dos nove do sucesso eleitoral, como o podem ser as redes de organizações paralelas típicas dos partidos de criação externa.

6 N.K.: Para um estudo do funcionamento da maioria das características desses partidos, veja Bardonnet (1960). 
em nome do interesse da comunidade comercial e industrial, poderiam substituir o povo em geral. ${ }^{7}$

Como esses partidos, se comparados com seus vizinhos alemães, tiveram que enfrentar um desafio menor advindo dos partidos de integração de base classista, eles puderam arcar com os custos de se tornar inoperantes em períodos de semicrises. Em tais períodos, nos anos 1920 e no início dos anos 1930, esses partidos, enquanto grupos coordenados que ocupavam cargos públicos, foram afiançados pelos procônsules salvadores, Poincaré, ${ }^{8}$ e seu imitador barato, Doumergue. ${ }^{9} \mathrm{E}$ ainda como correias de transmissão das opiniões, eles tiveram que lutar mais e mais contra os tumultos provocados pelas organizações antidemocráticas.

A última tentativa democraticamente legítima que a Terceira República fez para integrar a classe trabalhadora no sistema político foi com a Front populaire, de Léon Blum. ${ }^{10}$ Seu insucesso foi, em alguma medida, um fra-

N.K.: Daniel Bardonnet (1960, p. 251-256) contêm detalhes sobre o Comitê Mascuraud (batizada em homenagem ao senador do distrito de Seine), oficialmente chamado de Comitê Republicano do Comércio e da Indústria, a maior agência para a distribuição de fundos comerciais e industriais aos partidos burgueses. Para mais informações sobre esse comitê e outros canais que se tornaram mais importantes depois, veja também Ehrmann (1957, p. 219 e seguintes).

8 N.T.: Raymond Poincaré (1860-1934), primo do célebre matemático Henri Poincaré, foi ilustre político francês, de posição conservadora e nacionalista. Foi deputado, senador, ministro da educação e também da fazenda, chegando a ocupar o cargo de primeiro-ministro por três vezes (1912, 1922 e 1926) e até a Presidência da República, entre 1913 e 1920. Ajudou a fundar, em 1902, aquele que viria a ser o maior partido de centro-direita da Terceira República, a Aliança Republicana Democrática. Em sua primeira estadia no cargo de primeiro-ministro, implementou uma séria de medidas para preparar a França para uma guerra, que já antevia, contra a Alemanha. Assim, estreitou relações com a Inglaterra e a Rússia e fortaleceu seu exército, além de intensificar o serviço militar. Depois da Primeira Guerra, investiu numa séria de políticas agressivas contra os alemães, chegando a invadir a região do Ruhr, em janeiro de 1923.

9 N.T.:Trata-se de Pierre-Paul-Henri Gastón Doumergue (1863-1937), outro conhecido político francês da Terceira República. Doumergue foi primeiro-ministro duas vezes, ambas por períodos bastante breves. A primeira vez foi de Dezembro de 1913 a Junho de 1914; a segunda vez foi por poucos meses em 1934. Em 1917, recebeu a importante missão de ir à Rússia para tentar convencer Kerensky (então o primeiro-ministro do governo provisório) a não selar nenhum acordo de paz em separado com a Alemanha e a Áustria. Em 1924, chegaria à Presidência da República. Como presidente, Doumergue foi bastante popular, mas como primeiro-ministro, principalmente em 1913/1914, foi considerado pouco original e nada autônomo. Doumergue foi o primeiro protestante a ocupar o cargo de presidente.

10 N.T.: A Front populaire foi uma aliança dos movimentos de esquerda, formada no período do Entre-Guerras, com a participação do Partido Comunista Francês, do Partido Socialista Radical e da Seção Francesa da Internacional Trabalhista (SFIO). Essa frente conseguiu conquistar a maioria das cadeiras legislativas na eleição de 1936, o que possibilitou a formação de um governo de esquerda comandado por André León Blum (1872-1950), líder da SFIO e um político considerado de esquerda moderada. Ainda bem jovem, Blum foi bastante impactado pelo famoso caso Dreyfus, chegando a se engajar na campanha contra a condenação daquele capitão de ascendência judaica. Em decorrência disso, acabou conhecendo Jean Jourès, importante militante socialista. Provavelmente devido a essa influ- 
casso dos partidos e uma consequência de eventos internacionais. Com seu fracasso, a Terceira República, com sua justaposição dos clãs parlamentares burgueses e com os partidos de integração de base classistas, estava perto do fim.

Como foi que a Quarta República falhou na integração do Partido Comunista em seu sistema político e permitiu que tanto a SFIO (secção francesa da Internacional Operária ou Partido Social Democrata) ${ }^{11}$ como o MPR (Movimento Popular Republicano ou Partido Democrata Cristão) ${ }^{12}$ deslizassem para hábitos de partidos burgueses de períodos anteriores? Deveríamos destacar dois fatores de carga: os supervenientes e mutuamente exclusivos compromissos de política internacional da maioria dos partidos políticos franceses e os comunistas, assim como a crise da descolonização? Ademais, o fim do tripartidarismo, em 1947, não precisou deter a transformação dos partidos franceses em organizações hábeis para integrar os maiores grupos sociais no sistema político e capazes de atuar em coalizão - em colaboração ou em rotatividades alternativas. Não houve motivo para que o desafio do personalismo, na forma de gaullismo, e o desafio da oposição por princípio, da classe trabalhadora comunista, tivessem que implicar num retorno atávico ao sistema partidário dos anos 1920. A descolonização era um desafio que

ência, Blum se filiou ao Partido Socialista, chamado, à época, de SFIO. Depois de uma rápida ascensão na estrutura partidária, chegou a ser eleito deputado por Paris, dando início a uma longa e destacada carreira política, sendo o primeiro socialista e primeiro judeu a ocupar o cargo de primeiro-ministro naquele país.

11 N.T.: A SFIO (Section Française de L'Internationale Ouvrière) foi um partido criado em 1905, com a finalidade de tentar unificar as ações do movimento socialista na França. Depois da Comuna de Paris, o movimento socialista foi duramente atacado e acabou bastante dividido. Logo após o congresso de 1904, da Segunda Internacional, em Amsterdam, realizou-se, em 1905, o Congresso Global de Paris, no qual finalmente se conseguiu unificar dois dos principais partidos socialistas daquele país naquela época, o Partido Socialista da França e o Partido Socialista Francês. O primeiro tinha a liderança de Jules Guesde, que arrogava para si e seu partido a chancela do marxismo (inclusive, Guesde e Paul Lafargue, genro de Karl Marx e uma das lideranças da SFIO, são as duas figuras que teriam inspirado a conhecida frase de Marx: "se eles são, tenho certeza de que não sou marxista"), e o segundo era liderado por Jean Jaurès, de orientação social-democrata. Mas essa união durou pouco; no congresso de 1920, o bloco majoritário da SFIO votou favoravelmente à adesão à Internacional Comunista (Comintern ou Terceira Internacional), o que levou à criação da Section Française de L'Internationale Communist (SFIC). O grupo minoritário, porém, liderado por León Blum, decidiu permanecer vinculado à Segunda Internacional e manter a SFIO. Em 1969, depois de uma redução gradativa em seu desempenho eleitoral ao longo dos anos, a SFIO se transformou no atual Partido Socialista francês.

12 N.T.: O Mouvement Républicain Populaire era uma partido democrata-cristão, criado na Quarta República (1946-1958), como resultado do movimento de resistência cristã aos ataques à lgreja vindos dos republicanos, desde meados do século XIX. Durante os anos 1940, o MRP obteve grandes votações, enquanto um partido de direita, rivalizando eleitoralmente com o Partido Socialista e o SFIO. 
os partidos poderiam ter encarado com propostas políticas bem demarcadas. A integração da classe trabalhadora e o processo de descolonização - o primeiro já na agenda política virtualmente há meio século, e, o último, um problema limitado - eram encargos que um sistema partidário operante poderia ter administrado.

Além disso, em sua maioria, os partidos políticos franceses nunca progrediram para além do estágio de mensageiros do interesse local e dos clubes parlamentares, com ou sem tonalidades ideológicas. Eles foram igualmente incapazes de fazer compromissos em nome de seus eleitores ou de obter legitimidade por meio da transformação das opiniões e atividades daqueles em demandas convertidas em ação governamental. Eles, portanto, tiveram pouco que ver com a continuidade do Estado, que permanece como um negócio da burocracia. As principais opções sociopolíticas foram evitadas, ou, se e quando elas tiveram que ser enfrentadas, tornaram-se tarefas de políticos individuais apoiados temporariamente por fortes elementos da comunidade. É duvidoso até mesmo que uma combinação como a de Caillaux ${ }^{13}$ e Jaurès, ${ }^{14}$ a qual apareceu na primavera de 1914, teria sido capaz de caracterizar o partido como uma efetiva correia de transmissão entre a população e o governo, assim como uma base para a formulação das políticas. Essa falha deve ter ocorrido porque os burgueses desgostam dos dispositivos que poderiam transmitir e, desse modo, aumentar a pressão popular sobre a ação política. Na tarefa de

13 N.T.: Líder dos Radicais, Joseph-Marie-Auguste Caillaux (1863-1944) foi primeiro-ministro francês de 1911 a 1912, reconhecido por sua incansável tentativa de promover uma aproximação maior de seu país com a Alemanha, com a finalidade de estabelecer uma relação pacífica entre as duas nações. Os Radicais eram o resultado de um movimento republicano de esquerda que surgiu em oposição ao governo de restauração monárquica, depois da derrocada do império napoleônico, em 1815. Tal denominação se consolidou especialmente durante a chamada "monarquia de Julho"(1830-1848), sob o reinado de Louis-Philippe e sua constituição liberal. Os radicais tomaram parte ativa na Revolução de 1848 e na implantação da Segunda República (1848-1851).

14 N.T.: Jean Léon Jaurès (1859-1914) foi um dos mais conhecidos socialistas franceses, de oratória memorável. Jaurès era adepto da estratégia social-democrata para a realização da revolução socialista, ou seja, em sua perspectiva, a luta de classes deveria ser resolvida não pela violência, mas pela democracia. Sua formação acadêmica foi na famosa École Normale Supérieure, de Paris, onde obteve a agrégation em Filosofia e foi colega e amigo de Émile Durkheim, chegando inclusive a torná-lo simpático ao socialismo. Depois, foi professor no Liceu de Albi e conferencista da Universidade de Toulouse, onde ajudou a fundar a Faculdade de Medicina. Em 1885, dá início mais formal à sua carreira política, ao ser eleito deputado sucessivas vezes, com a exceção da eleição de 1898, quando foi derrotado provavelmente em decorrência de seu intenso envolvimento no caso Dreyfus, fazendo a defesa pública de sua libertação. Em 1904, funda o importante jornal oficial do Partido Comunista, o L'Humanité. A partir dos anos 1910, torna-se cada vez mais pacifista e se apresenta como um dos grandes opositores à guerra contra a Alemanha. Por causa disso, acabou sendo assassinado por um jovem nacionalista e partidário da guerra, que, de fato, viria a ocorrer pouco depois. 
carga única, relativa à integração dos couches populaires na polis francesa, a performance do partido político permanece inexpressiva.

A emergência das organizações partidárias italianas e alemãs, na metade do século XIX, não pode ser separada da história da unificação atrasada. A unificação foi um esforço competitivo entre os empreendimentos políticos de Cavour, Garibaldi e seus adeptos na Itália, ${ }^{15}$ e Bismarck ${ }^{16}$ e os liberais na Alemanha. Respectivamente, o timing e as ações desses estadistas não podem ser entendidos sem que se considere a urgência dessas pressões competitivas. Mas, as ágeis mãos de Cavour proveram o sistema partidário com maiores chances do que o destacado punho de Bismarck? ${ }^{17} \mathrm{O}$ que significam os estilos de unificação de Cavour e Bismarck em termos das chances e das cargas partidárias?

Poderia a esquerda italiana, o Partito d'Azione, ${ }^{18}$ ter tentado estabelecer contato com as massas camponesas do sul ${ }^{19}$ Por intermédio de tal contato, esse partido poderia ter estabelecido uma base para qualquer lealdade nacional que transcendesse essa classe e essa região? Ou era inevitável que o partido tivesse se tornar, por lado, testemunha, por outro, vítima de um transformismo que permaneceu essencialmente como uma operação comercial, ao invés de um instrumento de integração nacional? As possibilidades talvez tenham sido escassas, mas, de toda maneira, qualquer

15 N.T.: O autor faz referência a duas das mais importantes personagens do processo de unificação italiana. O Conde de Cavour, Camillo Paolo Giulio Benso (1810-1861), foi um vigoroso político e homem de negócios, fundador do jornal Risorgimento e do original Partido Liberal italiano, deputado e primeiro-ministro (1852) do Reino de Piemonte-Sardenha. Giuseppe Garibaldi (1807-1882) foi um militar italiano de intenso ativismo belicoso, tomando parte em vários levantes rebeldes e revolucionários. Integrou o grupo dos Carbonari, uma espécie de sociedade revolucionária secreta italiana, fundada no começo do século XIX, com uma ideologia liberal e patriótica, mas vaga e sem programa definido. Depois de uma rebelião fracassada, Garibaldi se refugiou no Brasil, onde acabou tomando parte bastante ativa na Guerra dos Farrapos, na região Sul, assim como na guerra civil uruguaia. Retornou à Itália em 1848 e viria a ser um dos principais comandantes do processo de unificação, tornando-se um herói da nação e um dos símbolos do Risorgimento.

${ }^{16}$ N.T.: Obviamente, o autor se refere a Otto Leopold Eduard (1815-1898), Príncipe de Bismarck, ou apenas Otto Bismarck, o famoso "Chanceler de Ferro", ministro-presidente da Prússia (1862-1890) e chanceler da Alemanha, em 1873. Como se sabe, suas políticas levaram à unificação da Alemanha.

17 N.K.: Um autor alemão recentemente abordou o caso desse modo:"a política Bismarck com os liberais foi injusta, na medida em que ele obteve o que os liberais queriam ter obtido, mas ele sequer Ihes deu a chance ou os meios para fazerem tal conquista por conta própria" (Pikart, 1962, p. 12-15).

${ }^{18}$ N.K.:Também conhecido como PdA, esse é um partido italiano criado em 1942 e extinto em 1947. De posição antifascista, republicana e moderadamente socialista, o PdA se inspirou no partido de mesmo nome fundado em 1853 pelo filósofo e político Giuseppe Mazzini (1805-1872), grande ativista em favor da unificação italiana. Com essa perspectiva, o primeiro Partito d'Azione fazia defesa do Risorgimento.

19 N.K.: Esse ponto é discutido com algum detalhe por Gramsci (1949, p. 100-104). 
tentativa nesse sentido jamais chegou a ser feita. Na Alemanha, por sua vez, mesmo o atraso e a fórmula da "Pequena Alemanha" envolvida na fundação do Reich de Bismarck não evitaram que aquela criação rapidamente se tornasse uma unidade social e economicamente viável. Todas as forças políticas, sejam amigáveis ou hostis em relação ao "pai fundador", aceitaram seu Reich como uma base de operação. Mas, no que se refere às chances dos partidos políticos, os resultados não foram muito diferentes. A Itália encontrou uma solução fictícia para seus problemas de identidade nacional, trabalhável constitucionalmente, mas não em termos sociopolíticos. Os herdeiros de Bismarck, as forças combinadas da burocracia, do exército, dos industriais e agricultores, na Prússia e no Império, mais ou menos ao mesmo tempo mantiveram um arranjo constitucional que evitou qualquer abordagem relacionada à participação efetiva da classe trabalhadora no governo. Tanto na Itália como na Alemanha, a péssima administração das crises de identidade nacional e da participação fez recrudescer o problema da carga que as nações tinham que encarar ao final da Primeira Guerra Mundial. Todavia, seria difícil avaliar os impactos distintos desses fatores de carga, se comparados com a França, por exemplo. Lá, sem nenhuma crise de identidade nacional, a longa e latente crise de participação tornou-se francamente aberta em meados dos anos 1930. Eu argumentaria, inclusive, que a extensão do colapso de 1940 está claramente relacionado com essa crise de participação.

Então, o conceito de carga é útil na análise da falha dos partidos continentais quanto a assumirem seus papéis apropriados nos anos 1920? Podemos argumentar, por exemplo, que o atraso em aceitar um regime constitucional, que teria permitido que a democracia política se tornasse plenamente efetiva, impediu a bem sucedida integração política nas classes trabalhadores no sistema político alemão nos anos 1920? A aceitação desse argumento depende de mais diferenciações. Por “integração política” queremos dizer a capacidade de um sistema político fazer com que os grupos e seus respectivos membros, previamente excluídos da política oficial, convertam-se em plenos participantes do processo político. Muitos dos partidos de massa, entretanto, sequer foram capazes de ou interessados em integrar seus membros na comunidade política existente. Ao contrário, o partido pode até mesmo querer incluir seus seguidores em suas fileiras para colocá-los em confronto com o aparelho de Estado. 


\section{II. $O$ antebellum ${ }^{20}$ : partido de integração da massa}

Os partidos socialistas do período da virada do século exerceram uma importante função de socialização de seus membros. Eles facilitaram de muitas maneiras a transição da sociedade agrária para a industrial. Eles sujeitaram um considerável número de pessoas, até então vivendo tão apenas como indivíduos isolados, à disciplina voluntariamente aceita e que operava em próxima conexão com as expectativas de uma total transformação futura da sociedade. Mas, essa disciplina tinha suas raízes na alienação desses partidos em relação ao sistema político do período pré-Primeira Guerra Mundial, cuja morte eles queriam garantir e até mesmo acelerar, mediante suas tentativas de impressionar a população como um todo com suas atitudes exemplares. ${ }^{21}$

Durante e imediatamente após a Primeira Guerra Mundial, os outros participantes do jogo político mostraram que ainda não estavam desejosos de honrar os clamores dos partidos de massa da classe trabalhadora - clamores baseados nas regras formais da democracia. Essa descoberta foi uma das principais razões explicativas para o porquê da integração social no sistema industrial, por meio das organizações da classe trabalhadora, não ter avançado ao estágio de uma integração política comparável. Participação na guerra, as longas querelas acerca da incidência dos encargos financeiros da guerra, a devastação inflacionária, o surgimento dos partidos bolcheviques e de um sistema soviético que competia ativamente pela lealdade da massa com as organizações de massa já existentes na maioria dos países europeus, e, finalmente, o efeito do cenário de depressão ao final da década - todas essas coisas eram agentes muito mais efetivos na politização das massas do que sua participação em eleições ocasionais, do que sua luta pela extensão do sufrágio (Bélgica, Grã-Bretanha e Alemanha) ou até mesmo do que seu encadrement nos partidos políticos e nas organizações sindicais. Mas, politização não é o equivalente a integração política; integração pressupõe uma boa-vontade geral da sociedade para oferecer e aceitar uma parceria

\footnotetext{
${ }^{20}$ N.T.: Este é um termo latino, também grafado Ante Bellum, cujo significado é pré-guerra. O autor se refere, obviamente, ao período imediatamente anterior à Primeira Guerra Mundial.

${ }^{21}$ N.K.: O final alemão dessa história e a emergência de Bebel como comandante-em-chefe de um contraexército bem disciplinado têm sido comentado freqüentemente. Isso foi bem discutido recentemente por Roth (1963). Observações similares sobre a função integrativa do socialismo são igualmente válidas para a Itália. Essencialmente hostil, um observador como Benedetto Croce (1963) nota tais fatores in seu History of Italy; Robert Michels (1925, p. 270 e seguintes) apresenta amplas provas documentais sobre isso, em seu Sozialismus in Italien.
} 
política plena, sem reservas, de todos os cidadãos. As consequências da integração no partido de massa classista dependem das respostas das outras forças existentes no sistema político; em alguns casos, tais respostas foram tão negativas que conduziram à integração atrasada no sistema político ou então à desintegração.

Agora voltemos nossa atenção para o outro lado dessa falha em progredir da integração num partido de massa proletário e na sociedade industrial como um todo ${ }^{22}$ para a integração no sistema político propriamente. Essa é a falha dos partidos burgueses em avançar dos partidos da representação individual para partidos da integração, um fracasso já notado na França. As duas tendências, a falha na integração dos partidos de massa proletários no sistema político oficial e a dos partidos burgueses em avançar até o estágio dos partidos integrativos, condicionam-se mutuamente. Uma exceção, pelo menos parcial, é a dos partidos confessionais, ${ }^{23}$ tais como o Centro Alemão ou o Partito Popolare, de Don Sturzo. ${ }^{24}$ Até certo ponto, esses partidos preenchem ambas as funções: integração social na sociedade industrial e integração política no âmbito do sistema político existente. Não obstante, sua natureza confessional deu-lhes uma força de caráter que restringiu seriamente seu crescimento potencial. ${ }^{25}$

22 N.K.: Integração à sociedade industrial: enquanto o trabalhador aceitou alguns aspectos, tais como a urbanização e a necessidade de regularidade e as vantagens correspondentes de uma sociedade de consumo de massa, viu-se impotente enquanto indivíduo e eternamente dependente de diretrizes pelos superiores, o que redunda em atitudes fortemente escapatórias. Esses problemas são discutidos em detalhes por Andrieux e Lignon (1960). As consequências ambíguas a serem extraídas desses fatos e seus impactos amplamente negativos sobre a imagem política dos trabalhadores são estudadas detalhadamente por Popitz et al. (1957).

${ }^{23}$ N.K.: Para a tipologia dos partidos religiosos, veja Maier (1959).

${ }^{24}$ N.T.: O Partito Popolare Italiano (PPI) foi fundado em 1919, com a autorização do Papa Bento XV, tendo como orientação a doutrina social da Igreja Católica. Com esse partido, os católicos italianos dispunham novamente de uma organização para atuar na política do país, depois de várias décadas da linha proposta de não-participação estabelecida pela Igreja. Seu fundador, Don Luigi Sturzo (1871-1959), era conhecido como um socialista clerical. Seus pendores socialistas o levou a ser exilado da Itália, em 1924, quando da ascensão do fascismo. Esse partido deixou de existir em 1926. Em 1995, surgiu outro partido com o mesmo nome, como resultado da renovação interna da Democrazia Cristiana. Esse novo PPI, no entanto, em 2000, fundiu-se com o partido Democrazie è Libertá, mais conhecido como La Margherita. Seu último congresso aconteceu em 2002, quando suas atividades foram interrompidas. A ala do PPI descontente com a fusão criou, em 2003, a Italia Popolare, um movimento político e cultural. A ala que se fundiu com la Margherita, em 2007, juntou-se ao Partito Democrático, fundado nesse mesmo ano e posicionado na centro-esquerda.

25 N.K.: Há outros partidos que constituem outra exceção, tais como o Partido Nacionalista Alemão dos anos 1920, cujo predecessor conservador dos dias anteriores à Primeira Guerra Mundial já tinha lucrado com a habilidade de representação dos interesses agrários (Landbund) para afunilar apoio estável o suficiente para a organização de seus companheiros no mercado político. Veja, em geral: Nipperdey (1961, vols. V e VI). 
Com essas exceções parciais, os partidos burgueses não mostraram qualquer capacidade para se transformar de clubes para a representação parlamentar em agências para a política de massa, com habilidade para barganhar com o partido de massa do tipo integrador, de acordo com as leis do mercado político. Havia apenas um incentivo limitado para a organização intensiva do partido burguês. $\mathrm{O}$ acesso aos favores do Estado, mesmo após a democratização formal, permaneceu reservado aos meios educacionais ou a outros privilégios de classe. $\mathrm{O}$ que faltava aos burgueses em termos numéricos, poderia ser superado por intermédio de relações estratégicas com o exército e a burocracia.

Gustav Stresemann ${ }^{26}$ é o político que empacou na encruzilhada dessa era, operando com um conjunto triplo e incompatível de partidos: os democráticos partidos de massa classistas e os confessionais; os partidos de oposição-por-princípio, integradores das massas à sua moda contra a ordem existente; e os velhos partidos da representação individual. Sempre à procura de compromissos viáveis entre os democráticos partidos de massa, os partidos burgueses do velho estilo da representação individual e os detentores do poder externos à estrutura política partidária formal, Stresemann não logrou resultados. O partido da representação individual, do qual ele provinha, não poderia lhe dar uma base ampla o suficiente para suas políticas. ${ }^{27}$

Nem todos os grupos burgueses aceitaram a necessidade de se transformar em partidos da integração. Enquanto tais grupos tiveram outros meios de acesso ao aparelho de Estado, eles acharam conveniente retardar o arranjo de contrapesos aos partidos de massa existentes, e ainda se mantiveram a utilizar os aparelhos estatais para evitar que os partidos de integração de massa se tornassem completamente efetivos no mercado político. Contudo, depois da Segunda Guerra Mundial, a aceitação da lei do mercado político tornou-se algo inevitável na maioria dos países da Europa Ocidental. Essa mudança, por sua vez, encontrou eco na mutante estrutura dos partidos políticos.

\footnotetext{
${ }^{26}$ N.T:: Chanceler e ministro das relações exteriores da Alemanha, do período conhecido como República de Weimar. Ele foi indicado para o cargo durante a crise política envolvendo a ocupação da região do Ruhr pela França e a Bélgica, entre 1923 e 1925, e governou com uma ampla coalizão de partidos. Kirchheimer faz alusão aqui a tal coalizão. Gustav Stresemann (1878-1929) fez um grande esforço para tentar reconciliar a Alemanha com a França, estimulando, inclusive, os moradores do Ruhr a manifestarem uma resistência pacífica contra os invasores. Em decorrência disso, Strasemann recebeu, em 1926, o prêmio Nobel da paz.

27 N.K.: Veja as conclusões de Hartenstein (1962) e Turner (1963).
} 


\section{O partido catch-all ${ }^{28}$ do pós-guerra}

Logo depois da Segunda Guerra Mundial, o partido burguês, do velho estilo da representação individual, tornou-se exceção. Enquanto alguns exemplares da espécie ainda sobrevivem, a natureza dos sistemas partidários, não obstante, já não é mais determinada por eles. Do mesmo modo, o partido da integração das massas, produto de uma era na qual havia uma rígida linha divisória entre as classes e estruturas de clivagens mais marcadamente protuberantes, está se transformando num partido popular catch-all. ${ }^{29}$ Abandonando seus esforços antes voltados para o enquadramento intelectual e moral das massas, esse partido está se concentrando mais completamente no cenário eleitoral, na tentativa de trocar a efetividade do debate mais aprofundado por uma audiência mais ampla e pelo sucesso eleitoral mais imediato. Essa tarefa política mais estreita e esse objetivo eleitoral imediato

${ }^{28}$ N.T.: Pode haver certa controvérsia quanto ao termo catch-all. Em alemão, língua original do autor, o equivalente seria allerweltsparteien, algo como"partido de todo mundo". Uma analogia aproximativa em português poderia ser"partido guarda-chuva" ou até mesmo aquilo que já foi conhecido como"partido-ônibus". Mas, há quem sustente que há certas sutilezas da língua alemã que permitem interpretações diferentes e que não respaldariam a tradução que se fez para o inglês, ou seja, o termo catch-all, pois alguns dos sentidos desse termo em alemão acabariam se perdendo - o conhecido lost in translation. Para evitar tais polêmicas, mantenho aqui o termo em inglês, sem traduzi-lo para "pega-tudo", como se convencionou fazer alhures e até em outras línguas, como o italiano. Além disso, o termo catch-all foi escrito pelo próprio Kirchheimer, dado que, ao que tudo indica, ele mesmo redigiu esse texto em inglês, e não em alemão. A prova disso, embora circunstancial, pode ser encontrada na nota de rodapé inicial (p. 177), escrita por LaPalombara, um dos editores do livro, dando conta de que apenas revisões de menor importância foram feitas no texto original, dado que Kirchheimer mesmo não pode fazer nenhuma alteração em virtude de sua morte pouco antes da publicação. Outra prova circunstancial é o próprio estilo da redação; quem quer que leia o texto no original, perceberá que não foi mesmo um nativo da língua que o escreveu e que a maneira de se expressar é muito característica de alguns autores alemães quando escrevem em inglês. Por último, em minha interpretação, ao fim e ao cabo, o termo em alemão e em inglês, na verdade, abrangem o mesmo tipo de fenômeno. Aproveito o ensejo para agradecer à colega Silvana Krause por ter chamado minha atenção para a necessidade de fazer tais esclarecimentos acerca desse conceito.

29 N.T.: No texto, a expressão que aparece nesta altura é "catch-all 'people's party" (p. 184); depois, em todas as outras ocorrências, a expressão é "catch-all 'peoples' party". Na tradução, a decisão foi sempre manter a expressão tal como aparece neste ponto inicial: "partido popular catch-all." Não está claro se o autor considera que seria possível um partido catch-all que não fosse popular; tampouco se ele pretendeu dar a conotação norte-americana ao termo "people's party", geralmente considerado um partido populista, ou se queria dizer que se trataria de um partido popular. Populista e popular são duas coisas bem diferentes e, para nós da América Latina, seria contraditório supor a existência de um partido populista se nos mantivermos rigidamente apegados à definição canônica do conceito "populista". Populista pode ser um político ou certas políticas, mas não um partido, dado que o populismo tem como uma de suas características centrais a relação direta entre a liderança pessoal do político - geralmente uma liderança carismática - e o povo. Um líder populista opera acima e à margem do partido. Desse modo, pareceu mais sensato considerar a expressão desse modo,"partido popular", embora isto também seja um tanto vago, mas é algo que se deve à imprecisão conceitual deixada pelo autor e ao caráter oral do texto, o qual não foi devidamente revisado antes da publicação, em virtude da morte repentina de Kirchheimer. 
diferem agudamente daquelas preocupações anteriores mais abrangentes; hoje tais preocupações são vistas como contraproducentes porque afastam segmentos de uma clientela potencialmente mais nacional.

No caso dos partidos de massa classistas, ainda que rudimentarmente, podemos distinguir três estágios aos quais foram submetidos nesse processo de transformação. Primeiramente, houve o período de reunião de forças, que durou até o começo da Primeira Guerra Mundial; então vieram suas primeiras experiências no governo durante os anos 1920 e 1930 (MacDonald, República de Weimar, Front Populaire), de certo modo insatisfatórias se confrontadas com as expectativas tanto dos seguidores dos partidos de massa classistas como das próprias lideranças, o que indicava a necessidade de uma base mais ampla de consenso no âmbito do sistema político. Esse período é seguido pelo estágio presente mais ou menos avançado de formação de grupos partidários do tipo catch-all, no qual alguns dos partidos ainda tentam manter sua clientela especial, a classe trabalhadora, e, ao mesmo tempo, procuram atrair uma variedade de outras clientelas.

Podemos identificar algumas regras segundo as quais essa transformação toma seu curso e selecionar os fatores que promovem, atrasam ou impedem esse processo? Poderíamos considerar a corrente taxa de desenvolvimento econômico como a mais importante determinante; mas se isso fosse tão relevante, a França certamente estaria à frente da Grã Bretanha e, da mesma forma, também à frente dos Estados Unidos, que ainda são o exemplo clássico de um sistema partidário predominantemente catch-all. E que tal o impacto da continuidade ou descontinuidade do sistema político? Se isso fosse assim tão importante, a Alemanha e a Grã Bretanha estariam no pólo oposto do espectro, ao invés de apresentarem uma velocidade de transformação similar. Devemos então nos contentar em fazer alguns comentários sobre os padrões gerais e registrar fatores limitantes especiais.

Em alguns casos, a performance dos partidos catch-all encontra limites impostos pelo estrutura tradicional da sociedade. Na Itália, o difuso background religioso da Democrazia Cristiana ${ }^{30}$ implica, logo de início, que o

\footnotetext{
${ }^{30}$ N.T.: Como já mencionado, trata-se de um partido italiano, fundado em 1943, com a intenção de ser o herdeiro eleitoral do Partito Popolare Italiano original, fundado em 1919, por Don Luigi Sturzo. A Democrazia Cristiana (DC) adotou a mesma orientação ideológica e até o mesmo símbolo do PPI. Além disso, acomodava em suas fileiras facções as mais variadas, indo da direita até a esquerda, o que acabou lhe conferindo o status de um exemplar do que Kirchheimer chamaria de partido do tipo catch-all.
} 
partido não poderá ser bem sucedido se fizer apelos aos elementos anticlericais da população. Por outro lado, nada impede que o partido verbalize seus apelos de modo tal que consiga maximizar suas chances de capturar mais daqueles numerosos elementos que não se perturbam com suas ligações clericais. Já há algum tempo, o elemento solidário do núcleo-duro de sua doutrina vem sendo empregado de maneira bem sucedida no que se refere à atração de uma clientela socialmente diversificada.

Ou consideremos o caso de dois outros grandes partidos europeus, o SPD alemão (Partido Social Democrata) ${ }^{31}$ e o Partido Trabalhista britânico. ${ }^{32}$ É improvável que qualquer um deles seja capaz de fazer alguma concessão aos desejos específicos dos reais interesses imobiliários ou dos operadores independentes das propriedades agrícolas e, ao mesmo tempo, manter intacta qualquer credibilidade diante das massas da população urbana. Felizmente, todavia, os assalariados urbanos, ou trabalhadores manuais e gerentes suburbanos e servidores públicos têm interesses convergentes a tal ponto que é possível designá-los como objetos estratégicos de apelos simultâneos. Então, a tradição e o padrão da estratificação social e profissional podem fixar limites e oferecer audiências potenciais aos apelos do partido.

\footnotetext{
${ }^{31}$ N.T: O SPD é o Sozialdemokratische Partei Deutschlands, o Partido Social Democrata alemão. Segundo dados do próprio partido, sua criação se deu em 1863, por Ferdinand Lassalle, sob a inicial denominação Associação Geral dos Trabalhadores Alemães (Allgemeiner Deutscher Arbeiterverein - ADAV). Mais à frente, em 1869, August Bebel e Wilhelm Liebknecht fundaram o Partido Social-Democrata dos Trabalhadores Alemães (Sozialdemokratische Arbeiterpartei), que viria a se fundir com a ADAV em 1875, quando da realização do Congresso de Gotha (cujo programa mereceu a famosa crítica de Karl Marx). A junção dessas duas organizações levou à criação do Partido Socialista dos Trabalhadores Alemães (SAPD), que, devido ao seu viés socialista, acabou sendo considerado ilegal por Bismarck, em 1878. Em 1890, o SAPD voltou à legalidade e, no mesmo ano, na Conferência de Halle, decidiu finalmente adotar o nome Partido Social-Democrata Alemão (SPD). Por volta da virada do século XIX para o século XX, o SPD já era a maior organização partidária do mundo, com crescente número de filiados. Em 1905, contava com cerca de 384 mil membros; em 1913, eles eram mais de um milhão. 0 SPD também foi o objeto do estudo clássico de Robert Michels, com base no qual chegou à formulação de sua célebre "lei de ferro da oligarquia". O partido também era considerado o grande exemplar de um partido de massa, conforme a tipologia de Maurice Duverger, pois desenvolvia intensas atividades de recrutamento e de socialização política, com cursos livres, palestras, peças de teatro e até uma escola para a educação dos trabalhadores. Atualmente, o SPD é um dos dois maiores partidos da Alemanha,

32 N.T.: Trata-se do Labour Party, fundado no século XIX com total vinculação com o movimento sindical, o que o levou a adotar uma postura socialista democrática de centro-esquerda. Sua entrada na competição eleitoral desafiou o rígido sistema bipartidário britânico, dominado pelo Partido Liberal e o Partido Conservador. Os trabalhistas chegaram ao poder pela primeira vez somente em 1924, num governo de coalizão (hung parliament) em que eram minoritários. Em 1929, finalmente ultrapassaram a votação dos liberais, tornando-se definitivamente uma das duas forças partidárias principais da política do Reino Unido, ao lado dos conservadores. Desde então, o Partido Trabalhista governou de 1945 a 1951, de 1964 a 1970, de 1974 a 1979 e de 1997 a 2010.
} 
Se o partido não pode almejar capturar todas ${ }^{33}$ as categorias de eleitores, não obstante, pode nutrir uma expectativa razoável de capturar mais eleitores de todas aquelas categorias cujos interesses não lhe tragam algum conflito danoso. Diferenças marginais entre as reivindicações dos grupos, tais como aquelas entre os grupos gerenciais e de trabalhadores manuais, podem ser suavizadas por meio da ênfase vigorosa em programas que beneficiem a ambos os grupos igualmente; por exemplo, alguma política de compensação contra os choques da automação.

Ainda mais importante é a pesada concentração em temas que possam muito remotamente encontrar resistências por parte da comunidade. Metas societárias nacionais que transcendam os interesses de grupos são mais vantajosas a um partido que intencione estabelecer ou alargar seu discurso anteriormente limitado a nichos específicos da população. O partido que, por exemplo, faz propaganda de forma mais agressiva em favor de um sistema educacional mais inclusivo pode ouvir, das elites que previamente gozavam de privilégios nesse setor, protestos retumbantes sobre seus custos excessivos ou mesmo sobre o perigo que essa massificação representa para a qualidade da educação. Mesmo assim, os dividendos do partido com qualquer outra família podem ser influenciados somente pelo quanto este aceitou a nova prioridade nacional mais rápida e agressivamente do que seu maior competidor, e o quanto sua propaganda vincula eficazmente o futuro individual da família às estruturas educacionais mais amplas. Relativamente a isso, sua clientela potencial é quase ilimitada. A performance como catch-all em relação a uma dada categoria se converte virtualmente numa performance de catch-all ilimitada.

Esta última observação já transcende os confinamentos dos grupos de interesse. Por um lado, nessas sociedades desenvolvidas com as quais estou lidando, graças aos níveis gerais de conforto econômico e segurança, e aos esquemas existentes de bem-estar universalizados pelo Estado ou obtidos por barganhas coletivas, muitos indivíduos já não precisam de tal proteção, uma vez que eles procuraram obtê-la do Estado. Por outro lado, muitos se tornaram cônscios a respeito da quantidade e da complexidade dos fatores gerais de que seu bem estar depende. Essa mudança de prioridades e

33 N.T.: No original em inglês, a expressão é "if the party cannot hope to catch all categories of voters" (p. 186). Aqui, o autor mantém o termo aplicado ao "tipo" partidário, mas utiliza a acepção corriqueira do verbo "to catch", por isso a decisão de traduzir como "capturar". 
preocupações pode conduzi-los ao exame das ofertas políticas por uma ótica menos focada nos seus interesses particulares e mais concentrada nos aspectos relativos à habilidade política dos líderes no que se refere a lidar com futuras contingências gerais. Dentre os maiores partidos da atualidade, a emergente UNR francesa (União Nacional Republicana) ${ }^{34}$ é quem especula mais claramente acerca da possibilidade da canalização de suas necessidades menos especializadas, às quais seu padroeiro De Gaulle constantemente apela, seguindo os moldes de sua versão particular de partido catch-all. Seus ativos assumidos repousarão em uma doutrina de propósitos nacionais e de vaga unidade, mas flexível o bastante para permitir as mais matizadas interpretações e ainda - pelo menos enquanto o General continuar em suas funções - atrativas o suficiente para servir como ponto de encontro para muitos grupos e indivíduos isolados. ${ }^{35}$

Assim, enquanto a UNR manipula a ideologia para ter o máximo de apelo geral, notamos que, no caso da Democrazia Cristiana, a ideologia é um fator levemente limitante. A ideologia da UNR, em princípio, não exclui ninguém. A ideologia da democracia cristã, por definição, exclui os não-cristãos, ou pelo menos os eleitores seriamente não-cristãos. Esse partido paga o preço das ligações com a solidariedade religiosa e as vantagens das organizações de apoio repelindo alguns milhões de eleitores. Os partidos catch-all na Europa apareceram num tempo de desideologização, o qual contribuiu substancialmente para sua emergência e proliferação. A desideologização no campo político envolve a transferência da ideologia da filiação numa estrutura de metas políticas claramente visíveis para uma das muitas, suficientes mas nem de perto necessárias, forças motivacionais que operam na escolha dos eleitores. Nas últimas duas décadas, os partidos social democratas da Alemanha e da Áustria deram mostras da política da

\footnotetext{
${ }^{34}$ N.T.: O autor se refere, na verdade, à L'Union pour la Nouvelle Républic, um partido criado em 1958 especialmente para apoiar Charles de Gaulle na eleição presidencial do mesmo ano. Em 1962, a UNR se juntou com a Union Démocratique Du Travail (UDT), uma organização claramente gaullista, formando a UNR-UDT. Logo depois, em 1967, os candidatos do partido concorreram sob a sigla Union Démocratique pour la Vo Republique (UD-Vo). Adotou um novo nome em 1968, Union pour la Défense de la Republique, e, em 1971, outro nome, Union des Démocrates pour la Republique.

35 N.K.: As dificuldades de um partido no qual a dinâmica da personalização substitui completamente as metas fixadas por acordo, assim como o estilo das operações revestindo as variantes de lealdade pessoal do partido catch-all, tornam-se prontamente aparentes a partir da descrição do Terceiro Congresso da UNR, feita por Charlot (1964, p. 86-94).
} 
desideologização. O exemplo da União Democrática Cristã (CDU) ${ }^{36}$ alemã é menos evidente só porque havia pouco o que desideologizar. Na CDU, a ideologia era, desde o início, somente uma atmosfera de fundo geral, tanto bem abrangente como convenientemente vaga o bastante para permitir o recrutamento de denominações católicas e protestantes.

Via de regra, somente os maiores partidos podem se tornar partidos catch-all de maneira bem sucedida. Nem um partido pequeno ou estritamente regional, como o Partido do Povo do Tiról do Sul, ${ }^{37}$ nem um partido erguido em torno de um comprometimento ideológico grosseiro e limitado, como o Partido Calvinista Holandês; ou reivindicações de grupos transitórios, como os refugiados alemães; ou as reivindicações de alguma categoria profissional específica, como os agricultores suecos; ou um programa de ação limitado, tal como o do Partido "da taxa-única" da Justiça dinamarquês; ${ }^{38}$ nenhum desses pode aspirar a uma performance do tipo catch-all. Sua raison dêtre é a defesa de uma clientela específica ou o lobby por uma reforma limitada, claramente delineada para permitir um apelo restrito, talvez intenso, mas que exclui um impacto de maior amplitude, ou - uma vez que o trabalho original tenha se encerrado - que exclui uma transformação salvadora.

A performance do tipo catch-all não está em voga e nem mesmo é objetivada pela maioria dos grandes partidos das pequenas democracias. Se-

${ }^{36}$ N.T.: Christilich Demokratische Union Deutschlands, um partido conservador, de centro-direita, fundado em 1945, logo ao final da Segunda Guerra, com o propósito de ser uma organização interconfessional, congregando militantes católicos e protestantes, e orientado por valores cristãos e pela doutrina liberal-conservadora. Dentre seus fundadores, figurava Konrad-Adenauer, que viria a ser o primeiro Chanceler escolhido pelo partido, quando chegou ao poder pela primeira vez, já em 1949. Desde então, a CDU se transformou num dos principais protagonistas da política alemã, chegando a governar o país nos períodos de 1949 a 1969 (Konrad-Adenauer, Ludwig Erhard e Kurt Kiesinger), de 1982 a 1998 (Helmut Khol) e de 2005 até o momento (Angela Merkl). Tradicionalmente, faz alianças com seu congênere da região da Baviera, a União Social-Cristã (Christlich-Soziale Union in Bayern - CSU), na conhecida coligação "União"CDU/CSU.

${ }^{37}$ N.T.: Tiról do Sul é uma província autônoma no norte da Itália. O Partido do Povo do Tiról do Sul foi fundado em 1945, para representar a população de línguas alemã e ladina. Desde que disputou sua primeira eleição, em 1948, esse partido sempre recebeu a maioria dos votos em sua região, majoritariamente de língua alemã.

${ }^{38}$ N.T.: O autor faz aqui um trocadilho com os dois nomes pelos quais o partido era e ainda é conhecido. Oficialmente, trata-se do Partido da Justiça, mas correntemente ele também é denominado Partido da Taxa-Única. Fundado em 1919, sua inspiração foi buscada no pensamento do economista norte-americano Henry George, defensor de que todos os bens naturais são necessariamente coletivos, principalmente a terra, por isso ela deveria ser a única fonte de taxação. Todo o resto, criado pelos homens, seriam produtos de seus trabalhos e, portanto, deveriam ser possuídos apenas por eles mesmos, e não partilhados com outros ou com os governos, por meio dos impostos. 
guramente entrincheirados, frequentemente gozando de status majoritário por décadas - como os partidos social-democratas norueguês e sueco - e acostumados a uma grande quantidade de cooperação interpartidária, ${ }^{39}$ tais partidos não têm incentivos para mudarem suas formas de recrutamento ou seus apelos a grupos sociais bem definidos. Com menos fatores intervenientes e, por consequência, com menor visibilidade acerca dos resultados futuros das ações e decisões políticas, parece ser mais fácil estabilizar as relações políticas com base nas competições estritamente circunscritas (o caso da Suíça, por exemplo) do que mudar para formas mais aleatórias da competição do tipo catch-all.

A conversão para o tipo de partido catch-all é um fenômeno associado à competição. Um partido está sempre apto a se acomodar aos estilos bem-sucedidos de seus competidores, por esperar os mesmos benefícios ou ter medo de perdas no dia da eleição. De modo oposto, quanto mais um partido se convence de que os resultados favoráveis de um competidor dever-se-iam somente a algumas circunstâncias não repetíveis, e que a capacidade do competidor de superar dissensões internas é um fenômeno temporário, menor é a chance de uma conversão completa e maior é a inclinação para agarrar uma leal - embora limitada - clientela.

Para avaliarmos o impacto dessas mudanças, considero ser útil listar as funções exercidas pelos partidos europeus durante suas primeiras décadas (no final do século XIX e começo do século XX) e compará-las com a situação presente. Os partidos têm funcionado como canais para a integração de indivíduos e grupos na ordem política existente, ou como instrumentos para a modificação ou a substituição completa dessa ordem (integração-desintegração). Os partidos lograram determinar as preferências por certas ações políticas, assim como influenciar outros participantes do processo político a aceitá-las. Os partidos vêm indicando os ocupantes dos cargos públicos e apresentando-os à comunidade política para sua confirmação.

A assim chamada "função expressiva" ${ }^{0}$ dos partidos, se não pertence a uma categoria por si mesma, todavia demanda uma palavra especial. Seu ponto culminante se deu no constitucionalismo do século XIX, quando exis-

\footnotetext{
${ }^{39}$ N.K.: Torgersen (1962) e Rokkan e Valen (1963, especialmente p. 29). Tanto por motivos históricos como por razões contemporâneas, o Partido Social-Democrata austríaco constitui exceção parcial à regra das tendências menos claras de transformação, se comparado com outros grandes partidos de massas de países pequenos. Para um tratamento mais adequado, veja Shell (1962).

40 N.K.: Cf. Sartori (1966; 1957).
} 
tia uma separação mais demarcada entre a formação-expressão da opinião e os negócios de governo. Naquela época, os partidos criados internamente ao parlamento expressavam opiniões e críticas amplamente compartilhadas pela minoria educada da população. Eles pressionavam os governos com tais opiniões. Mas, como os governos repousavam largamente sobre bases constitucionais e sociais independentes, eles poderiam, caso necessário, garantir-se contra as investidas das facções parlamentares e dos clubes. A total democratização fundiu a opinião-expressão e os negócios de governo nos mesmos partidos políticos e os colocou na cadeira seja do governo efetivo ou de um governo alternativo. Porém, isso deixou a função expressiva dos partidos numa situação ainda mais ambígua. Por razões eleitorais, o partido catch-all democrático intenciona lançar da maneira a mais abrangente possível uma rede sobre uma clientela potencial; deve continuar a expressar os amplos sentimentos de preocupação popular. Além do mais, empenhado em continuar no poder ou em se mover em direção ao poder governamental, ele desempenha essa função expressiva sujeita a múltiplas restrições e a considerações táticas cambiantes. O partido atrofiar-se-ia se não mais pudesse ser capaz de funcionar como intermediário na relação entre a população e a estrutura de governo, captando queixas, ideias e problemas desenvolvidos numa roupagem mais perscrutadora e sistemática em outras partes do corpo político. Já a cautela que deve ter em relação ao seu papel governamental no presente ou prospectivamente requer modulagem e restrição. A natureza mesma dos atuais partidos catch-all proíbe qualquer escolha entre essas duas performances. Ela requer dos partidos uma alternância constante entre os papéis de crítico e de apoiador do establishment; uma mudança dura de executar, porém, ainda mais dura de ser evitada.

Com a finalidade de deixar o máximo de sua marca na comunidade política, um partido tem que exercer todas as três primeiras funções. Sem a habilidade para integrar as pessoas na comunidade, o partido poderia não compelir os outros detentores do poder a ouvir o toque de seus clarins. $\mathrm{O}$ partido influencia outros centros de poder na medida em que as pessoas estejam desejosas de seguir sua liderança. Inversamente, as pessoas são desejosas de ouvir o partido porque este é portador de mensagens - aqui considerado como ação segundo as preferências - que estão ao menos parcialmente de acordo com as imagens, desejos, esperanças e medos do eleitorado. Indicações para os cargos públicos servem para atar todos esses 
propósitos; elas possibilitam, além disso, a realização de preferências por certos cursos de ação se isso extrai respostas positivas dos eleitores ou dos detentores do poder. As indicações concretizam a imagem partidária com o grande público, de cuja confiança ele depende.

Agora podemos discutir a presença ou ausência dessas três funções nas sociedades ocidentais de hoje. Sob as condições presentes de proliferação das orientações seculares e de consumo de massas, com os mutantes e menos intrusivos alinhamentos de classe, os antigos partidos de massa classistas e os partidos de massa confessionais estão sob pressão para se transformar em partidos populares catch-all. $\mathrm{O}$ mesmo se aplica àqueles poucos remanescentes dos antigos partidos burgueses da representação individual, os quais almejam garantir algum futuro político enquanto organizações independentes dos caprichos das leis eleitorais e dos movimentos táticos dos concorrentes, os partidos de massa. ${ }^{41}$ Essa mudança envolve: a) a drástica redução da bagagem ideológica do partido. Na França, para o SFIO, por exemplo, os resquícios ideológicos servem quando muito como uma insuficiente cobertura para o que se tornou conhecido como "Molletisme", ${ }^{42}$ o reino absoluto das considerações táticas de curto-prazo; b) Maior estreitamento entre os grupos de lideranças do topo das organizações, cujas ações e omissões agora são julgadas a partir do ponto de vista de sua contribuição à eficiência de todo o sistema social, ao invés de sua identificação com as metas particulares de suas organizações; c) Rebaixamento do papel do membro partidário individual, um papel tido

\footnotetext{
${ }^{41}$ N.K.: Partidos liberais sem um programa com perfil bem definido ou uma clientela podem, no entanto, realizar tal conversão. Val Lorwin chamou minha atenção para o excelente exemplo de um ex-partido burguês, o Partido Liberal belga, que, em 1961, tornou-se o Partido da Liberdade e do Progresso, retirando a ênfase que dava ao anticlericalismo e voltando seus apelos à ala direita do Partido Social Cristão, preocupado com a aliança governamental entre este e os socialistas.

42 N.T.: Este termo foi cunhado pela esquerda francesa para descrever um comportamento político contraditório de quem se apresenta discursivamente como de esquerda radical, mas, na prática, quando no governo, faz políticas moderadas e se alia com a direita. Trata-se de uma alusão a Guy Mollet (19051975), um político francês que iniciou sua trajetória política ainda bem jovem ao aderir a SFIO, em 1923. Desde então, envolveu-se intensamente em atividades e organizações de esquerda, chegando a fazer parte da resistência francesa durante a Segunda Guerra. Em 1945, foi eleito deputado e, entre 1946 e 1969, foi líder da SFIO, sendo um dos mais destacados membros da ala esquerda do partido e severo defensor da unidade partidária contra uma possível fragmentação em várias facções de centro. Em 1946, tornou-se vice-primeiro-ministro e, em 1950-1951, foi ministro das relações exteriores europeias. Entre 1951 e 1969, foi vice-presidente da Internacional Socialista e chegou a ser primeiro-ministro da França em 1956-1957. Apesar do discurso e da atuação como militante de esquerda, ao chegar à chefia do governo, Mollet acabou se aliando com partidos de centro e de centro-direita, o que lhe valeu essa "homenagem" pela criação de um dos "verbetes" da política francesa.
} 
como uma relíquia histórica que pode obscurecer a imagem reconstruída do renovado partido catch-all; ${ }^{43} \mathrm{~d}$ ) Perda da ênfase na classe gardée, na classe social específica ou na clientela confessional em favor do recrutamento de eleitores da população em geral; e) Garantia do acesso à variedade de grupos de interesse. As razões financeiras são óbvias, mas elas não são os fatores mais importantes em locais onde o financiamento é viável, como na Alemanha, ou onde o acesso aos meios de comunicação mais importantes é aberto e imparcial, como na Inglaterra e na Alemanha. A principal razão, portanto, é a garantia do suporte eleitoral via intermediação dos grupos de interesse.

Os partidos comunistas da França e da Itália, algumas vezes considerados os dois velhos partidos de massa remanescentes, estão se autoexcluindo desse desenvolvimento regular e universal. Esses partidos estão parcialmente ossificados e parcialmente solidificados em decorrência da combinação de rejeição oficial com legítimas reclamações seccionais. Nessa situação, a invocação cerimonial do rápido desaparecimento do cenário de fundo de uma remota e impraticável experiência revolucionária ainda não foi totalmente abandonada como parte da estratégia política. Mas, qual é a posição de tais partidos de oposição, do velho tipo partido de massa classista, que, invejosos, tentam manter uma lealdade exclusiva de seus membros, enquanto não admitidos no e nem totalmente preparados para partilhar o hostil poder do Estado? Tais partidos enfrentam as mesmas dificuldades de outras organizações políticas para recrutar e manter os membros intensamente interessados. E ainda, em contraste com seus competidores que trabalham dentro dos confinamentos da ordem política existente, eles não podem fazer da necessidade uma virtude, de modo a procurarem se adaptar plenamente ao novo estilo do partido popular catch-all. ${ }^{44}$ Esse conservadorismo não lhes custa a confiança de seu corpo regular de eleitores. Mas, por outro lado, a contínua renovação dessa confiança no dia da eleição não envolve um laço íntimo o suficiente para ser utilizado como uma base para operações políticas maiores.

\footnotetext{
43 N.K.: Amplos materiais sobre os pontos b e c podem ser encontrados no interessante estudo realizado por um político alemão: Lohmar (1963, especialmente p. 35-47 e 117-124). Veja também Pizzorno (1964, p. 199-217).

${ }^{44}$ N.K.: Entretanto, mesmo na França - para não falar da Itália -, as políticas dos comunistas estão sofrendo pressão para se acomodar a esse novo estilo. Para um exemplo concreto recente, veja Andrews (1963, p. 308-326). Mais recentemente, Duverger (1964, p. 33-49).
} 
As atitudes dos eleitores regulares - em contraste com as dos membros partidários e ativistas - confirmam o grau de incongruência entre a participação plena nos processos da sociedade orientada ao consumo de mercadorias e o velho estilo político que repousa sobre a necessidade social de uma radical mudança política. Esta opinião ficou fora de moda nos países ocidentais e vem sendo cuidadosamente subtraída das expectativas, dos cálculos e símbolos do partido de massa catch-all. A incongruência pode se assentar na total ausência de qualquer conexão entre o comportamento sociocultural geral e o estilo político. ${ }^{45}$ Nesse sentido, a escolha eleitoral pode se basear na tradição familiar ou na empatia com algum político pobre coitado, sem que isso, no entanto, se transforme em alguma parte coerente da estrutura da personalidade. $\mathrm{Ou}$ então a escolha eleitoral pode ser feita na expectativa de que esta não terá influência no curso do desenvolvimento político; assim, esta é um ato seja de ajuste ao sistema político existente ou, conforme o caso, de desvinculação desse sistema, e não a manifestação de vinculação a qualquer outra coisa.

\section{O partido catch-all, o interesse de grupo e o eleitor: integração limitada}

O potencial de integração do partido de massa catch-all baseia-se na combinação de fatores cuja finalidade resultante visível é a atração do máximo número de eleitores no dia da votação. Para obter tal resultado, o partido catch-all deve ter conseguido entrar em milhões de mentes como se fora um objeto familiar, preenchendo na política um papel análogo àquelas grandes marcas no mercado de artigos de consumo de massa universalmente necessários e altamente estandardizados. Não importa quais sejam as particularidades inerentes ao líder partidário, que, inclusive, garantiram sua ascensão no interior da organização, assim que for selecionado para a liderança, ele deve adaptar rapidamente seu comportamento segundo os requisitos da padronização. Há a necessidade de alguma diferenciação da marca, de modo a tornar o produto plenamente reconhecível, porém, o grau dessa diferenciação jamais deve ser tão elevado a ponto de fazer com que o potencial consumidor tema ser relegado ao limbo.

Como as marcas cujos nomes se tornaram uma palavra familiar, o partido de massa catch-all que já governou um país por algum tempo e tem líderes

${ }^{45}$ N.K.: Essa hipótese é discutida com mais detalhes por Lavau (1962, especialmente p. 198). Para outras explicações veja Lipset (1964, p. 271-303). 
conhecidos pelos eleitores, seja pela televisão ou pelas colunas dos jornais, goza de uma grande vantagem. Mas isso só até certo ponto. Devido a certas circunstâncias possivelmente fora do controle partidário ou mesmo da oposição - um escândalo nas esferas de governo, uma crise econômica -, manter um cargo público de repente pode se tornar um símbolo negativo, encorajando o eleitor a trocar de partido da mesma maneira que troca uma marca por outra concorrente.

As regras que decidem o resultado da competição de um partido de massa catch-all são extremamente complexas e aleatórias. Quando um partido possui ou procura uma base eleitoral de potencial quase nacional, composta por uma maioria de indivíduos cuja relação com a política é tanto tangencial como descontínua, os fatores que podem decidir o eventual resultado eleitoral são quase infinitos e frequentemente não relacionados com a performance partidária. O estilo e a aparência do líder, o impacto de um evento recente totalmente imprevisto, período de férias, o clima quando afeta a colheita -fatores como estes afetam os resultados.

O próprio caráter catch-all do partido torna mais difícil qualquer expectativa de lealdade da militância ou, no melhor dos casos, ela nunca é suficiente para alterar os resultados. $O$ resultado de um debate televisivo é dúbio ou o debate em si mesmo constitui uma exposição muito fugaz para deixar alguma impressão duradoura até a eleição. Assim, o partido de massa catch-all também é voltado à busca de uma clientela mais permanente. Somente algum grupo de interesse, seja de natureza ideológica ou econômica, ou ainda uma combinação de ambos, é capaz de prover massivas reservas de eleitores prontamente acessíveis. Ele tem uma linha de comunicação mais constante e maior receptividade para suas mensagens do que as tem o partido catch-all, o qual é afastado do contato direto com o público, exceto pelo comparativamente menor número de indivíduos intensamente preocupados com a marca política que um partido tem que oferecer atualmente - ou com suas próprias carreiras seja dentro do partido ou por intermédio dele.

Do mesmo modo, o clima das relações entre o partido catch-all e os grupos de interesse definitivamente sofreram mudanças desde os gloriosos dias do partido de massa classista ou do partidos confessionais de integração. Ambos, os partidos e os grupos de interesse, obtiveram grande independência um do outro. Se eles ainda estão juntos numa mesma organização (como 
o Partido Trabalhista britânico e o TUC [Trades Union Congress] $)^{46}$ ou se gozam formalmente dessa completa independência mútua (como o SPD alemão e o DGB ${ }^{47}$ não importa, pois o que é mais relevante é a mudança de papéis. ${ }^{48}$ Em vez de uma estratégia conjunta focada numa meta comum, o que aparece nessa relação é a apreciação da oferta de préstimos limitados e talvez ainda mutuamente vantajosos.

A propensão partidária para atrair o máximo de eleitores deve regular suas relações com os grupos de interesse de uma forma a não rechaçar eleitores potenciais que se identificam com outros interesses. Por sua vez, o grupo de interesse nunca deve pôr todos os seus ovos numa única cesta. Isso poderia ofender as sensibilidades de alguns membros que porventura tenham conexões políticas diferentes. O mais importante é que o grupo de interesse não quererá reprimir sentimentos de esperança depositados em outro partido catch-all ao qual, com alguns movimentos em sua direção, poderá trazer recompensas eleitorais. Tanto o partido como o grupo de interesse modulam seus comportamentos, agindo como se a possível contingência já tivesse chegado, nomeadamente que o partido já tivesse capturado o governo - ou uma importante parcela dele - e se deslocado da posição de amigo ou conselheiro para a de juiz ou de árbitro. De repente, investido da confiança da comunidade como um todo, o partido-governamental arbitrador faz seu melhor quando consegue redefinir todo o problema e descobrir soluções que, pelo menos no longo prazo, funcionarão em favor de todos os interesses e reivindicações.

Aqui, portanto, emerge uma questão crucial: qual é então o papel próprio do partido catch-all na arbitragem dos conflitos de interesse? Nem todos os governos tentam alcançar a melhor posição tática para exercer uma arbitra-

\footnotetext{
${ }^{46}$ N.T.: Esta é uma federação sindical do Reino Unido, fundada em 1868, com a intenção de unificar as ações dos sindicatos e associações dos trabalhadores. Aprofundando ainda mais esse propósito, em 1899, a TUC aprovou uma moção para o estabelecimento de um instrumento de vocalização dos interesses dos trabalhadores no parlamento, o que levou à criação do Comitê de Representação Trabalhista. Esse foi o ponto de partida para o surgimento do Partido Trabalhista, cujas origens e desenvolvimento estão intrinsecamente associados aos sindicatos. O Partido Trabalhista surgiu como poderoso desafiante do duopólio predominante no mercado eleitoral britânico de então, com um sistema bipartidário protagonizado pelo Partido Conservador e o Partido Liberal. Nas primeiras eleições dos anos 1920, os trabalhistas ultrapassaram os liberais na proporção de votos para o parlamento, o que os levou a dominar o sistema bipartidário ao lado dos conservadores, situação que prevalece até hoje, mesmo com o crescente bom desempenho eleitoral dos liberais.

${ }^{47}$ N.T.: DGB é a Deutscher Gewerkschaftsbund, uma confederação sindical dos trabalhadores, fundada em 1949.

${ }^{48}$ N.K.: Veja as conclusões de Harrison (1960).
} 
gem efetiva das reivindicações dos grupos contenciosos? O partido catch-all é mesmo necessário nessa conexão? $\mathrm{Ou}$ - do ponto de vista do interesse pode a sociedade dispensar os serviços partidários, como faz a França hoje?

Um partido é mais do que um coletor de reivindicações dos grupos de interesse. O partido funciona, ao mesmo tempo, como advogado, protetor, ou pelo menos como canalizador das demandas de todos que não conseguem fazer sua voz ser ouvida de maneira tão efetiva quanto a dos que são representados por grupos de interesse bem organizados: aqueles que ainda não têm posições no processo de produção ou que já não ocupam mais tais posições, aqueles que são ainda muito jovens ou já muito idosos, e aqueles cujo status familiar os alinha mais com consumidores do que com os interesses dos produtores.

Podemos explicar esse fenômeno simplesmente como se tratasse de outra faceta da função agregadora do partido? O problema nesse caso é que a fraseologia funcionalista apenas reafirma ao invés de explicar. Os indivíduos desorganizados ou frequentemente desorganizáveis somente dão o ar de sua graça no dia da eleição ou em comitês pré-eleitorais e atividades partidárias repentinas arranjadas em seu benefício. Será o partido desejoso e capaz de tomar tais interesses em suas próprias mãos? Jogando com suas viabilidades eleitorais, será ele capaz não somente de checar as demandas mais extremas dos grupos organizados, mas também de transcender o nível presente das relações entre os grupos e, por reformas políticas, redefinir toda a situação política? Nenhuma fórmula fácil nos dirá qual habilidade do líder, que montante de pressão advinda das situações objetivas terão que intervir para produzir tais mudanças na configuração política.

Nessa tarefa de transcendência dos interesses dos grupos e de geração de confiança geral, o partido catch-all goza de certas vantagens, mas, pelos mesmos motivos, ele lida com uma fragilidade. Evitando o sectarismo, o partido aumenta suas chances de recrutamento em termos eleitorais, mas, inevitavelmente, limita a intensidade do compromisso que poderia esperar. A transformação do partido, que deixa de ser uma organização que combina a defesa da posição social, a imagem de um abrigo espiritual com a concepção de que deveria ser um veículo voltado a escolhas políticas de curto prazo e intersticiais, expõe-no aos riscos enfrentados por todos os fornecedores de bens de consumo não-duráveis: empacotar sua mercadoria da maneira mais atrativa para competir com uma marca similar. 


\section{Participação limitada na ação segundo a preferência}

A discussão nos traz agora à determinação da ação segundo a preferência e suas chances de se realizarem. No modelo bem conhecido de Anthony Downs, a ação segundo a preferência resulta simplesmente do interesse partidário por uma meta mais imediata, qual seja, vencer a próxima eleição. Por consequência, o partido cuidará para que os membros individuais da comunidade obtenham de suas políticas mais benefícios do que perdas. ${ }^{49}$ Frequentemente, embora não de forma exclusiva, as ilustrações de Downs são retiradas de áreas tais como a tributação, na qual uma equação de dividendos inerente à ação política é plausível. Porém, o próprio Downs notou ocasionalmente que satisfações ou insatisfações psicológicas, medos ou esperanças, são elementos tão frequentes nas decisões dos eleitores quanto o cálculo de benefícios de curto prazo ou privações. Se não fosse assim, dificilmente poderia ser explicada a longeva lealdade de enormes contingentes de eleitores em relação aos partidos de massa classistas integradores em situações de inexistência de qualquer benefício imediato advindo de tal filiação. Mas, poderíamos dizer que tais cálculos de curto prazo correspondem muito mais proximamente às atitudes relacionadas aos atuais partidos de massa catch-all com sua variada clientela? Essa abordagem centrada nos ganhos de curto prazo pode ser utilizada, por exemplo, na análise de questões militares ou de política exterior?

Em alguns países, na última década, tornou-se regra os partidos catch-all que estão na oposição simplesmente colocar na soleira da porta do governo as mais recentes falhas ou deterioração aparente da posição militar ou internacional do país, especialmente durante as campanhas eleitorais: assim fez o Partido Republicano ${ }^{50}$ em 1952, nos Estados Unidos, em relação à longa indefinição da Guerra da Coreia, ou os Social Democratas, na Alemanha, mais recentemente, em relação à aparente passividade de Adenauer ${ }^{51}$ diante

\footnotetext{
${ }^{49}$ N.K.: "O partido sempre organiza sua ação de modo a focar numa única quantidade: sua margem de votos em relação à oposição ao final do período eleitoral corrente" (Downs, 1957, p. 174).

50 N.T.: Fundado em 1854, por ex-membros dos Whigs e das Free Soilers, e também por ativistas antiescravidão e defensores da modernização do país, o Partido Republicano desafiaria a hegemonia do Partido Democrata, chegando à Presidência da República pela primeira vez em 1860. Junto com o Partido Democrata, o Partido Republicano vem dominando a cena bipartidária dos Estados Unidos da América há várias décadas.

51 N.T:. Konrad Hermann Joseph Adenauer (1876-1967) foi um político de intensa atividade no cenário alemão e europeu de meados do século XX. Um dos principais articulares da fundação da CDU, com o objetivo de congregar protestantes e católicos num mesmo partido, de orientação democrática
} 
do Muro de Berlim. Em outros exemplos, todavia, a oposição rebaixa as questões militares ou de política externa, ou as trata enquanto generalidades vagas o suficiente para evocar a imagem de si mesma como uma competidora que será capaz de lidar com elas tão bem como o faz o governo de turno.

Uma vez em que o sistema partidário ainda inclui partidos de integração do tipo de massa classista "não-reformados" ou - como no caso do Partido Socialista Italiano ${ }^{52}$ - somente "parcialmente-reformados", as questões militares ou de relações exteriores entram na campanha como diferenças políticas. E até mesmo aqui o maior interesse se afastou das áreas em que o eleitorado poderia exercer somente uma escolha ilusória. O eleitorado percebe que, nessa situação concreta, baseada em grande parte na geografia e na história, $\mathrm{o}$ alinhamento do país a algum bloco internacional, mais do que qualquer outra preferência por alguma política, irá formar a base para a tomada de decisão. Ele percebe também que tais decisões repousam apenas parcialmente, ou, às vezes, nominalmente, na liderança política. Mesmo que o impacto do líder político na decisão possa ter sido determinante, mais frequentemente do que se possa supor, os calendários eleitorais nas democracias têm importância reduzida, pois, uma vez implementada a decisão, esta não é mais contestada ou mesmo relevante para a escolha dos eleitores. Muito provavelmente, novos eventos desviarão o foco de atenção dos eleitores para outras questões. Poucos eleitores ainda pensam sobre a "deserção" de Mendès France ${ }^{53}$ da

e capitalista, mas ponderando-se tais elementos com os valores cristãos, Adenauer foi Chanceler da Alemanha entre 1949 e 1963, durante o difícil período de reconstrução do país, depois dos conflitos da Segunda Guerra. Em seu governo, além da reestruturação econômica, urbana e social da Alemanha, iniciou o processo de reconciliação de sua nação com os judeus e o resto da Europa.

52 N.T.: Este era o Partito Socialista Italiano (PSI), criado em 1892 por membros de diversas associações de trabalhos e de partidos de esquerda, como o Partito Operário Italiano (POI) e o Partito Socialista Rivoluzionario Italiano (PSRI). Foi um dos principais partidos do país até o final da Segunda Guerra, quando deu lugar ao Partito Comunista Italiano, que veio a ser dissolvido em 1994.

53 N.T.: Descendente de uma família portuguesa (Mendes de França), de origem judaica, que, por volta de 1506, teve de migrar para a França em virtude de perseguição religiosa, Pierre Mendès-France seria um personagem de grande importância na política francesa. Estudou direito na Universidade de Paris e, em 1924, filiou-se ao Partido Socialista Radical. Em 1932, foi eleito deputado para a Assembleia Nacional. Em 1936, foi nomeado secretário de Estado das finanças, do governo León Blum. Juntou-se à força aérea francesa durante a Segunda Guerra e acabou sendo acusado falsamente de deserção. Por isso, tornou-se prisioneiro em Vichy, cujo governo era nitidamente colaborativo com os nazistas. Escapou do hospital da prisão de maneira magistral e se refugiou na Inglaterra, onde veio a integrar o grupo França Livre, liderado por Charles de Gaulle. Foi então nomeado comissário de finanças, na Argélia, e fez parte da delegação francesa na conferência de Bretton Woods, em 1944. No mesmo ano, com a Paris liberta, de Gaulle Retorna à França, e Mendès-France é nomeado ministro da economia. Torna-se primeiro-ministro em 1954-1955 e tem em seu gabinete François-Mitterand, que viria a ser, décadas depois, o Presidente da República. A partir de 1958, veio a ser um forte opositor de de Gaulle. 
Indochina, em 1954, quando Edgar Faure ${ }^{54}$ repentinamente, dissolveu a Assembleia, em dezembro de 1955. Enquanto um partido pode se beneficiar com as decisões impopulares de seus adversários, tais benefícios são mais comumente um subproduto acidental do que o resultado do embate entre governo e oposição com papéis e escolhas claramente distribuídos.

Um partido pode apresentar propostas de políticas, mesmo vagas, que sejam razoavelmente coerentes para as áreas de relações exteriores ou militares, para propósitos eleitorais. Ele pode criticar a inépcia do governo de turno na lida com tais problemas, e essas críticas podem ser tornar mais e mais intensivas na medida em que o dia da eleição se aproxima. Mas, em nenhum dos casos, há qualquer garantia da habilidade do partido para agir como um corpo coerente no parlamento quando específicas preferências por certos cursos de ação estão por ser determinadas. A história do EDC, ${ }^{55}$ no parlamento Francês, e, mais recentemente, as batalhas dentro dos partidos britânicos com relação à entrada no Mercado Comum (embora o primeiro caso, por enquanto, permaneça inconclusivo por causa da forma pessoal com que De Gaulle pôs a questão) são exemplos ilustrativos desse dilema. Calendários eleitorais fortuitos, e as esperanças, os medos e as expectativas do público não se entrelaçam suficientemente com a ação descoordenada dos representantes parlamentares diante de questões concretas, a ponto de se somarem na definição de uma clara preferência partidária.

O partido catch-all contribui com programas gerais para a elaboração das preferências domésticas. Esses programas podem ser de prognóstico variado, informando o público a respeito de prováveis desenvolvimentos específicos e tendências gerais. Em realidade, prognósticos e desejos se sobrepõem como um borrão nesse tipo de futurologia, em que se vislumbra, através de lentes rosadas, a previsão de dias felizes para todos aqueles que estão entre os potenciais consumidores do partido. Esses programas podem conduzir ou se

\footnotetext{
${ }^{54}$ N.T.: Advogado notório e ativista da Terceira República, Edgar Faure (1908-1988) se filiou ainda jovem ao Partido Radical, por meio do qual fez grande parte de sua trajetória política. Foi membro da resistência francesa e participou do grupo de operações liderado por de Gaulle fora do país. Ao final da Segunda Guerra, atuou como um dos advogados de acusação nos julgamentos de Nuremberg. Em 1946, foi eleito para o parlamento e fazia oposição a Mendès-France dentro do partido, representando a ala mais à direita. De crítico passou a adepto do modelo político da Quinta República, vinculando-se ao grupo gaullista. Foi primeiro-ministro da França de janeiro a março de 1952.

55 N.T.: Esta é a sigla da European Defense Community, uma das primeiras propostas de uma instituição militar europeia, alternativa à NATO (North Atlantic Treaty Organization), apresentadas logo depois da Segunda Guerra. Tal proposta foi rejeitada pela Assembleia Nacional francesa em 1954.
} 
juntar a ações propositivas em vários estágios de concretização. Propostas concretas, todavia, sempre correm o risco de implicar em promessas que podem ser muito específicas. As concretizações devem permanecer gerais o suficiente para que não possam se converter, de armas eleitorais, em peças de ataques contra o partido que primeiro as mobilizou.

Essa indeterminação permite que o partido catch-all funcione como um ponto de encontro para a elaboração da ação concreta de uma multiplicidade de grupos de interesse. Tudo o que o partido pode requerer daqueles que obtêm seus serviços é que eles façam o máximo de esforço para chegar a compromissos que se delimitem ao seu enquadramento e que evitem se associar às forças que lhe são hostis. Os compromissos então elaborados devem ser aceitáveis aos maiores grupos de interesse, mesmo que esses grupos, por móvitos históricos ou por tradição, por ventura não estejam representados no partido governante. Diferenças marginais podem ser submetidas ao voto nas eleições, ou, como fazem ocasionalmente os antigos partidos de massa classistas, via referendo (Suíça e Suécia). Mas, esperadas alterações nas políticas são da natureza dos incrementos, ao invés de grandes mudanças nas relações entre os grupos.

É aqui que a diferença entre o tipo catch-all e a mais antiga forma do partido da integração se torna mais claramente visível. O partido catch-all fará seu máximo para estabelecer o consenso, de modo a evitar algum realinhamento partidário. $\mathrm{O}$ partido de integração até pode contar com a maioria dos mecanismos políticos para implementar seu programa, mas logo descobrirá que os interesses hostis frustram a decisão majoritária por meio dos mecanismos econômicos e sociais de que dispõem. Eles podem convocar greves (pelos trabalhadores, ou fazendeiros, ou lojistas, ou investidores), podem transferir seu capital para um paraíso fiscal seguro fora do país, podem solapar aquele fator sempre invocado hipocritamente, mas bastante real, conhecido como a "confiança da comunidade dos negócios".

\section{Integração por intermédio da participação na seleção da liderança: o futuro do partido político}

Que parte real da elaboração das preferências de ação resta ao partido catch-all? Sua maior contribuição consiste na mobilização dos eleitores para quaisquer cursos de ação preferenciais concretos que seus líderes sejam capazes de estabelecer, em vez de seleções a priori feitas pelos próprios votantes. 
É por essa razão que o partido catch-all prefere visualizar suas ações à luz das contingências, ameaças e promessas de situações históricas concretas, e não pela ótica das metas sociais em geral. O que é mais evidente é que esse é um papel esperado ou já estabelecido na dinâmica da ação, no âmbito da qual a vicária participação dos eleitores é uma convidada. Portanto, a atenção tanto do partido como do público em geral é focada mais claramente nos problemas relativos à seleção da liderança.

Nomeações significam a perspectiva de um cargo político. O cargo político oferece a chance de provocar algum impacto por meio da ação governamental. A competição entre aqueles que tentam influenciar as ações de governo põe em evidência que aqueles que estão na posição de poder agir antes de seus adversários têm uma vantagem política. O privilégio de agir primeiro é tudo de mais preciso numa situação nova e não-repetitiva, na qual o ator político pode evitar ficar enredado nas diretivas decorrentes das preferências do partido. Na medida em que o ator saúda o apoio partidário, baseado em princípios reverenciados (mas elásticos), ele se esquiva da direção específica e da supervisão. Nesse sentido, o partido catch-all fornece uma base ideal para a ação política. Quando a obtenção de cargos governamentais se torna uma preocupação quase exclusiva de um partido, problemas de pessoal são reduzidos à busca pelos meios mais simples e efetivos de ajeitar combinações vencedoras. A busca é especialmente efetiva onde quer que o partido se converta num canal por intermédio do qual os representantes de minorias até então excluídas ou negligenciadas podem se juntar à elite política existente.

Assim, a nomeação de candidatos para a legitimação popular enquanto titulares dos cargos de governo emerge como a mais importante função do atual partido catch-all. Sua concentração na seleção de candidatos para os cargos públicos está alinhada com a crescente diferenciação de papéis na sociedade industrial. Uma vez alcançados certos níveis de educação e bem estar material, tanto as necessidades intelectuais como as materiais são atendidas por especializados fornecedores de produtos econômicos e de comunicações. Da mesma forma, nos países industrializados do Ocidente, os partidos, que em sociedades menos avançadas ou naquelas que intencionam uma rápida mudança interferem diretamente na performance dos trabalhos societários, permanecem duplamente removidos - por intermédio do governo e da burocracia - do campo da ação direta. A esse estado de coisas, correspondem as atuais e prevalecentes imagens e expectativas populares 
em relação à redução do papel do partido. ${ }^{56}$ As expectativas previamente estabelecidas em relação à performance de uma organização política estão agora singrando por diferentes canais. ${ }^{57}$

Ao mesmo tempo, o papel do partido político enquanto um fator de continuada integração do indivíduo na vida nacional tem agora que ser visualizado sob um diferente matiz. Comparadas com sua conexão com as organizações de interesse e as associações voluntárias de natureza não-política, e com seu frequente encontro com a burocracia de Estado, as relações do cidadão com o partido político estão se tornando mais intermitentes e de escopo mais limitado.

Se assim o desejasse, o cidadão poderia estar mais próximo do velho partido da integração. Essa era uma organização menos diferenciada, em parte um canal de protesto, em parte um recurso para a proteção, em parte o fornecedor de uma visão do futuro. Agora, na sua descendência linear em um mundo transfigurado, o partido catch-all, o cidadão encontra apenas uma estrutura relativamente remota, às vezes quase-oficial e estranha. A sociedade democrática assume que o cidadão finalmente é um participante integral e consciente dos negócios políticos e econômicos; ela assume ainda que, como tal, o cidadão utilizará o partido como uma das muitas estruturas inter-relacionadas por meio das quais ele consegue uma participação racional em seu mundo circundante.

Devesse o cidadão viver sob tais pressupostos, tanto os indivíduos como a sociedade podem, de fato, encontrar no partido catch-all - não-utópico, não-opressivo e sempre flexível - um engenhoso e útil instrumento político.

E quanto à atitude dos poderosos que detêm cargos funcionais nas forças armadas, na burocracia, na indústria e nas organizações trabalhistas em relação ao moderno partido catch-all? Libertos de seus desnecessários medos anteriores, assim como das propensões ideológicas e intenções futuras do partido de massa classista, tais tomadores de decisão chegaram ao reconhecimento do papel do partido catch-all como um provedor de consenso. Em troca de sua habilidade para prover uma base de legitimidade claramente demarcada, esses detentores do poder funcionais estão, até certo ponto, dispostos a reconhecer as pretensões da liderança política desse partido. Eles

\footnotetext{
${ }^{56}$ N.K.: Veja a discussão sobre atitudes políticas em Habermas, et al. (1961), e a escala de preferências alemã, citada em Mayntz,(1960, p. 608-622).

57 N.K.: Veja a contribuição de Mallet (1962, especialmente p. 241-244).
} 
esperam isso para exercitarem certa função de árbitro nas relações intergrupais e para iniciarem limitadas inovações políticas. Quanto menos claramente demarcada a base eleitoral das reivindicações da liderança partidária, e quanto mais próxima a data da eleição, menor o crédito que esses detentores do poder funcionais darão às atividades não-solicitadas e não-rotineiras dos detentores do poder político que interferem em suas próprias posições. Essa ausência de credibilidade então prepara o palco para os conflitos entre as lideranças dos grupos funcionais e políticos. Como o partido catch-all que está no governo trata tais conflitos? Ele estará satisfeito em exercer pressão por meio dos meios de comunicação de massa, ou tentará recriar uma base de massa militante para além dos níveis evanescentes das eleições e da publicidade? Mas, a própria estrutura do partido catch-all, a frouxidão de sua clientela, podem, já de partida, excluir tais ações de maior alcance. Sendo assim, o papel do partido político na sociedade industrial ocidental da atualidade é muito mais limitado do que poderia parecer quando vislumbrada sua posição de preeminência formal. Por intermédio de seu papel governamental, ele funciona como coordenador e árbitro das relações entre os grupos de poder funcionais. Por meio de seu papel eleitoral, ele produz aquela porção limitada de participação popular e de integração requerida das massas para o funcionamento das instituições políticas.

Essa limitada participação oferecida pelo partido catch-all à população em geral, esse chamamento à participação racional e desapaixonada no processo político por intermédio de canais oficiais sancionados, poderá funcionar?

O instrumento, o partido catch-all, não pode ser muito mais racional do que seu amo: o eleitor individual. Não mais sujeito à disciplina do partido da integração - ou, como nos Estados Unidos, nunca sujeito à sua disciplina -, os eleitores poderão, por suas idiossincrasias e sua apatia, transformar o sensível instrumento do partido catch-all em algo bastante bruto para servir-lhe como um elo com os detentores do poder funcionais da sociedade. ${ }^{58}$ Então, ainda poderemos vir a nos arrepender do desaparecimento - mesmo que fosse inevitável - do partido de massa classista e dos partidos confessionais, assim como já nos arrependemos do desaparecimento de outras características do passado das civilizações ocidentais.

58 N.K.: Para algumas recentes restrições acerca da servidão partidária, dependente dos resultados eleitorais, veja Lohmar (1963, p. 106-108). 


\section{Referências bibliográficas}

ALAIN. 1925. Élements d'une doctrine radicale. Paris: Gallimard.

ANDREWS, W. G. 1963. "Evreux 1962: referendum and elections in a norman constituency". Political Studies, v. 11, p. 308-326.

ANDRIEUX, André \& LIGNON, Jean. 1960. Louvrier d'aujourd'hui. Paris: Librairie Marcel Rivière.

BARDONNET, Daniel. 1960. Évolution de la structure du parti radical. Paris: Éditions Montechretion.

CHARLOT, Jean. 1964. "Les troisèmes assises nationales de L'U.N.R.-U.D.T." Revue Française de Science Politique, v. 14, p. 86-94.

CROCE, Benedetto. 1963. History of Italy, 1870-1915. New York: Russell \& Russell.

DOWNS, Anthony. 1957. An economic theory of democracy. New York: Harper and Row.

DUVERGER, Maurice. 1964. "L'eternel marais: essai sur le centrisme Français". Revue Française de Science Politique, v. 14, p. 33-49.

EHRMANN, Henry W. 1957. Organized business in France. Princeton: Princeton University Press.

GRAMSCI, Antônio. 1949. "Il Risorgimento". Opere di Antonio Gramsci, v. 4, p. 100-104.

HABERMAS, Jürgen et al. 1961. Student und Politik. Neuwied/Berlin: Luchterhand.

HARRISON, Martin. 1960. Trade uninos and the labour party since 1945. London: George.

HARTENSTEIN, Wolfgang. 1962. Die Anfänge der Deutschen Volkspartei. Dusseldorf: Droste.

KIRCHHEIMER, Otto. 1966. "The transformation of the Western European party systems”. In: LAPALOMBARA, Joseph \& WEINER, Myron (orgs.). Political parties and political development. New Jersey: Princeton University Press, p. 177-200.

. 1990. "The transformation of the Western European party systems". In: MAIR, Peter (org.). The West European party system. Oxford: Oxford University Press.

LAPALOMBARA, Joseph \& WEINER, Myron. 1966. "The origin and development of political parties". In: LAPALOMBARA, Joseph \& WEINER, 
Myron (orgs.). Political parties and political development. New Jersey: Princeton University Press.

LAVAU, Georges. 1962. "Les aspectos sócio-culturels de la dépolitisation". In: VEDEL, Georges (ed.). La dépolitisation: mythe ou réalité? Paris: Armand Colin.

LIPSET, Seymour Martin. 1964. "The changing class structure and contemporary European politics". Daedalus, n. 93, p. 271-303.

LOHMAR, Ulrich. 1963. Innerparteiliche Demokratie. Stuttgart: Ferdinand Enke Verlag.

MAIER, Hans. 1959. Revolution und Kirche. Freiburg: Herder.

MALLET, Serge. 1962. "Laudience politique des syndicats". In: HAMON, Léo (ed.). Les nouveaux comportements politiques de la classe ouvrière. Paris: PUF.

MAYNTZ, Renate. 1960. "Loisirs, participation sociale et activité politique". Revue Internationale des Sciences Sociales, v. 12, n. 4, p. 608-622.

MICHELS, Robert. 1925. Sozialismus in Italien. Karlsruhe: Braun.

NIPPERDEY, Thomas. 1961. Die Organisation der Deutschen Parteien vor 1918, vols. V e VI. Dusseldorf: Droste.

PIKART, Eberhard. 1962. "Die Rolle der Deutschen parteien im Deutschen Konstitutionellen System”. Zeitschrift für Politik, n. 1, p. 12-15.

PIZZORNO, Alessandro. 1964. "The individualistic mobilization of Europe”. Daedalus, inverno, p. 199-217.

POPITZ, Heinrich et al., 1957. Das Gesellschaftsbild des Arbeiters. Tuebingen: J. C. B. Mohr.

ROKKAN, Stein \& VALEN, Henry. 1963. "Regional contrasts in Norwegian politics". Mimeografado.

ROTH, Guenther. 1963. The social democrats in imperial Germany. Ottawa: Bedminster Press.

SARTORI, Giovanni. 1957. Parties and party systems. New York: Harper and Row.

1966. "European political parties: the case of polarized pluralism". In: LaPALOMBARA, Joseph \& WEINER, Myron (orgs.). Political parties and political development. New Jersey: Princeton University Press.

SHELL, Kurt L. 1962. The transformation of Austrian socialism. New York: State University of New York.

TORGERSEN, Ulf. 1962. "The trend towards political consensus: the case of 
Norway". In: ROKKAN, Stein (ed.). Approaches to the study of political participation. Bergen: Christian Michelsen Institute.

TURNER, Henry A. 1963. Stresemann and the politics of the Weimar Republic. Princeton: Princeton University Press.

\title{
Resumo
}

Este texto foi o capítulo de um livro, publicado em 1966, que trazia resultados de pesquisas comparadas sobre os partidos políticos, sob a perspectiva do desenvolvimento político, e que foi parte de uma série de publicações intitulada Studies in political development. O tipo partidário catch-all, introduzido aqui por Kirchheimer, ainda é amplamente utilizado nos estudos partidários em todo o mundo, e este texto continua sendo um dos mais citados na Ciência Política até hoje. Embora a maior parte de seus escritos seja na língua alemã e, portanto, inacessível ao grande público, este pequeno trabalho em inglês, mais acessível, portanto, fez de Kirchheimer um dos autores mais conhecidos da área e deste texto uma leitura indispensável aos estudiosos dos partidos e da política em geral.

Palavras-chave: Kirchheimer; Otto Kirchheimer; Partido Catch-all; Catch-all; partido político.

\begin{abstract}
This is the chapter of a book, published in 1966, that presented the results of a comparative research agenda on political parties, from the perspective of political development. It was part of a series called Studies in political development. The concept of catch-all party type, introduced here by Kirchheimer, is still widely used in comparative studies on parties around the world, and this work remains one of the most cited in political science still today. Although most of his writing is in German, and therefore inaccessible to the general public, this little masterpiece written in English, thus more accessible for a large public, made Kirchheimer one of the best-known authors in political science, and this specific analysis an indispensable reading for scholars and anyone interested in politics in general.
\end{abstract} Key words: Kirchheimer; Otto Kirchheimer; Catch-all Party; Catch-all; political party. 